\title{
Effectiveness of non-pharmaceutical measures (NPIs) on COVID-19 in Europe: A systematic literature review
}

\author{
Authors: Constantine I. Vardavas ${ }^{1,2}$, Katerina Nikitara ${ }^{1}$, Katerina Aslanoglou ${ }^{1}$, Michele Hilton-Boon ${ }^{3}$, \\ Revati Phalkey ${ }^{4,5}$, Jo Leonardi-Bee ${ }^{4}$, Gkikas Magiorkinis ${ }^{6}$, Paraskevi Katsaounou ${ }^{7,8}$, Anastasia \\ Pharris $^{9}$, Ettore Severi ${ }^{9}$, Jonathan E. Suk ${ }^{9^{*}}$
}

\section{Affiliations}

1: School of Medicine, University of Crete, Greece

2: Department of Oral Health Policy and Epidemiology, Harvard School of Dental Medicine, Harvard University, Boston, MA, USA

3: WISE Centre for Economic Justice, Glasgow Caledonian University

4: Division of Epidemiology and Public Health, School of Medicine, University of Nottingham, UK

5: Climate Change and Health Group, Public Health England, United Kingdom

6: Department of Hygiene, Epidemiology and Medical Statistics, Medical School, National and Kapodistrian University of Athens, Greece

7: Department of Respiratory Medicine, National and Kapodistrian University of Athens, Athens, Greece

8: Pulmonary and Respiratory Failure Department, First ICU, Evaggelismos Hospital. Athens, Greece

9: European Centre for Disease Prevention and Control, Solna, Sweden

${ }^{*}$ Corresponding author: Jonathan E. Suk, jonathan.suk@ecdc.europa.eu, +46858601633. Gustav III:s Boulevard, 16973 Solna, Sweden. 


\section{Abstract}

Background: The study objective was to conduct a systematic review to assess the effectiveness of non-pharmaceutical interventions (NPIs) to reduce the transmission of SARS-CoV-2 in Europe during the first wave of the pandemic.

Methods: We searched OVID Medline, EMBASE, and the Cochrane and Campbell Databases for Systematic Reviews published up to April $15^{\text {th }} 2021$. Focusing on community (meso-level) and society (macro-level) level NPIs, we included all study designs, while a geographic restriction was limited to the EU, UK and European Economic Area (EEA) countries. Using the PICO framework, two reviewers independently extracted data and assessed quality using appropriate quality appraisal tools. A qualitative synthesis was performed, with NPIs grouped initially by a) Physical Distancing measures, b) Case detection and management measures, and c) hygiene measures and subsequently by country.

Results: Of 17,692 studies initially assessed, 45 met all inclusion criteria. Most studies $(n=30)$ had a modelling study design, while 13 were observational, one quasi-experimental and one experimental. Evidence from across the European continent, presented by country, indicates that the implementations of physical distancing measures (i.e., lockdowns/quarantines), preferably earlier in the pandemic, reduce the number of cases and hospitalisation across settings and for which the timing and duration are essential parameters. Case detection and management measures were also identified as effective measures at certain levels of testing and incidence, while hygiene and safety measures complemented the implementation of physical distancing measures.

Conclusions: This literature review represents a comprehensive assessment of the effectiveness of NPIs in Europe up to April 2021. Despite heterogeneity across studies, NPIs, as assessed within the context of this systematic review at the macro and meso level, are effective in reducing SARSCoV-2 transmission rates and COVID-19 hospitalisation rates and deaths in the European Region and may be applied as response strategies to reduce the burden of COVID-19 in forthcoming waves. 
medRxiv preprint doi: https://doi.org/10.1101/2021.11.11.21266216; this version posted November 11, 2021. The copyright holder for this preprint (which was not certified by peer review) is the author/funder, who has granted medRxiv a license to display the preprint in perpetuity.

It is made available under a CC-BY-NC-ND 4.0 International license .

\section{Introduction}

Since its emergence in December 2019 in Wuhan, China, and its spread across the globe, COVID-19 has developed into a pandemic, heavily impacting society and healthcare systems. As of September $26^{\text {th }}, 2021$, more than 37.5 million COVID-19 confirmed cases and 760,000 deaths had been reported in the European Union/European Economic Area (EU/EEA) (1). Undoubtedly, transmission is still widespread, although stable or decreasing hospitalisation and death rates were noted in most European countries during summer period, which has led to the reduction of non-pharmaceutical interventions (NPIs). However, the emergence of SARS-CoV-2 variants with increased transmissibility, notably the B.1.617.2 Delta variant (2), the strain on healthcare systems, the economic burden and seemingly plateauing vaccination coverage in the EU, may require continued large proportions of the population that remain unvaccinated to continue to implement NPIs as a public health response to the pandemic $(3,4)$. It is imperative that such decisions are based upon the best available evidence while also taking into account the context in which NPIs are implemented.

NPIs aim to reduce SARS-CoV-2 transmission through physical distancing and/or through minimising the risk of social interactions that may be larger than that (5). A broad range of different NPI responses has been adopted in Europe and worldwide, mainly in the control of other respiratory virus epidemics (6). NPIs implemented across Europe are numerous and include hygiene measures such as hand hygiene and protective mask-wearing, national or international travel bans and restrictions, physical distancing measures such as school and workplace closures and gathering bans, and health system measures such as testing and contact tracing strategies.

Determining the effectiveness of NPIs in specific regions and population groups is of high priority for policymakers, who must weigh a range of options that seek to enable social activities while also preventing SARS-CoV-2 transmission. The research community has dedicated significant resources to estimate the effectiveness of NPIs. As population concerns and individual behaviours have continuously been changing throughout the COVID-19 pandemic, targeted research efforts are needed to better understand changes in the effectiveness of NPIs with time and according to specific contexts. Given the abovementioned, this 
medRxiv preprint doi: https://doi.org/10.1101/2021.11.11.21266216; this version posted November 11, 2021. The copyright holder for this preprint (which was not certified by peer review) is the author/funder, who has granted medRxiv a license to display the preprint in perpetuity.

It is made available under a CC-BY-NC-ND 4.0 International license .

systematic review aims to assess the effectiveness of NPIs implemented in Europe, primarily up to early autumn of 2020, before vaccines were available.

\section{Methods}

\section{Search Results and PICO}

Relevant peer-reviewed studies were identified through systematic electronic searches using OVID Medline, EMBASE and the Cochrane and Campbell Databases for Systematic Reviews. The detailed search strategies for the biomedical databases are presented in Supplementary File 1 and included a timeframe between July $27^{\text {th }}, 2020$ and until April $15^{\text {th }}, 2021$ and were limited to the EU, UK and EEA countries, within the context of a service contract commissioned by European Center for Disease Prevention and Control (ECDC). Study designs included peer-reviewed studies including but not limited to: Simulation studies using mathematical models or transmission models, cluster and parallel randomised controlled trials (RCTs), cluster and parallel non-RCTs, quasi-experimental studies (including controlled before-after studies, uncontrolled before-after studies, time series, and interrupted time series) that assess the effectiveness of community nonpharmaceutical measures. Systematic and non-systematic literature reviews were identified, and reference lists were screened for identifying further studies.

The following set of inclusion criteria, based on the PICO framework (P-Population, I-Intervention, CComparison, O-Outcomes) for systematic reviews (7), was used to determine the eligibility of the studies and include: Populations were restricted to studies on humans, the assessed NPIs included community (mesolevel) and society (macro-level) mitigation measures for COVID-19, containing, but not limited to, closure of educational institutions, closure of public places (mandatory and voluntary), travel bans (closure of points of entry), travel advice, personal protective equipment, and physical distancing. Excluded interventions include individual (micro-level) measures, such as the individual effect of the use of personal protective equipment. The unmitigated pandemic, baseline, or the period before NPI implementation were used as the comparator. Finally, primary outcome measures include: i) COVID-19 cases, incidence and peaks, growth rate, and ii) R as 
medRxiv preprint doi: https://doi.org/10.1101/2021.11.11.21266216; this version posted November 11, 2021. The copyright holder for this preprint (which was not certified by peer review) is the author/funder, who has granted medRxiv a license to display the preprint in perpetuity.

It is made available under a CC-BY-NC-ND 4.0 International license .

an index of transmission. Secondary outcome measures include: i) mortality associated with COVID-19, ii) Intensive Care Unit (ICU) and hospital admissions.

\section{Study selection}

Studies identified from the searches were uploaded into a bibliographic database, and duplicates were removed. Initially, a pilot training title/abstract screening process was used, where a random sample of 100 titles was independently screened for eligibility by two reviewers to enable consistency in screening and identify areas for amendments in the inclusion criteria. A high measure of inter-rater agreement was achieved (percentage agreement $>90 \%$ ), and hence the remaining titles were distributed between the two reviewers and screened independently. For the full-text screening, a similar process was followed. Ten randomly selected studies were independently screened for eligibility by two reviewers (percentage agreement $>90 \%$ ), while the two reviewers subsequently screened the remaining full texts. Any disagreements were thoroughly discussed with a third reviewer.

\section{Data extraction, synthesis and presentation}

Data extracted were related to the study characteristics (first author's name, year of publication), geographical context (country/area), setting (where the measures were implemented), population characteristics, sample size, study type, numerical or descriptive findings with regards to the effectiveness of non-pharmaceutical measures in comparison to no intervention or current situation. Two reviewers independently piloted the data extraction template on a random sample of five included studies to assess consistency in data extraction and identify where amendments need to be made to the template. The remaining studies were then data extracted independently by the two reviewers.

The results from the studies for each intervention grouping are synthesised initially using a narrative synthesis. Characteristics of the included studies are also presented in the manuscript in tabulated form and provide details on the study design, geographical area, characteristics of the considered populations, setting, context, description of the studied NPIs and the qualitative and quantitative findings of the studies. The effectiveness of interventions is grouped based on the type of NPI. Areas of commonality between the 
medRxiv preprint doi: https://doi.org/10.1101/2021.11.11.21266216; this version posted November 11, 2021. The copyright holder for this preprint (which was not certified by peer review) is the author/funder, who has granted medRxiv a license to display the preprint in perpetuity.

It is made available under a CC-BY-NC-ND 4.0 International license .

results of the studies were identified through conducting a content analysis using an inductive approach, where the concepts are derived from the data. The categorisation primarily performed by the different types of NPIs is as follows:

$\checkmark$ Combined physical distancing measures: Combinations of travel restrictions, school and university closures, closure of non-essential businesses, teleworking, closure of entertainment venues, ban on events, restrictions on mass gatherings, stay-at-home orders, shielding of older people, self-isolation, quarantine of (suspected) cases, curfew, lockdown.

$\checkmark$ School closure: A few studies evaluated the individual effect of school closures and, hence, they are presented separately.

$\checkmark$ Case detection and management: Contact tracing, isolation of confirmed cases and quarantine of contacts/suspected cases.

$\checkmark$ Hygiene measures: Face mask and other protective equipment, disinfection of surfaces and air safety (from a meso or macro level).

The second level of grouping was performed by country as NPIs would be more comparable in the same setting, given that across countries, different combinations of NPIs were implemented in different timeframes and with varying levels of public compliance. Studies utilising combined data from multiple countries were also grouped together. Within the same country, studies are presented by study design, starting from the simulation studies and continuing with quasi-experimental and observational studies. As mentioned in the study of origin, the terms and descriptions of measures have been transferred verbatim to this systematic review and no new definitions have been developed. By that, lockdown includes a different combination of measures for each studied country.

\section{Assessment of Study Quality}

Given the various study types identified in this current review, multiple quality appraisal tools were applied to assess the included studies' quality. The Joanna Briggs Institute (JBI) standardised critical appraisal tools were used for RCTs, quasi-experimental and cohort studies (8), the Effective Practice and Organisation of 
medRxiv preprint doi: https://doi.org/10.1101/2021.11.11.21266216; this version posted November 11, 2021. The copyright holder for this preprint (which was not certified by peer review) is the author/funder, who has granted medRxiv a license to display the preprint in perpetuity. It is made available under a CC-BY-NC-ND 4.0 International license .

Care (EPOC) Risk of Bias tool for time series (9), and for modelling studies, a tool developed by Burns et al. (2020) was utilized (10). Three studies with a time trend analysis design were not appraised due to the lack of a reliable tool.

\section{Results}

\section{Study Selection}

A total of 17,692 studies were identified through systematic electronic searches across Medline and Embase. After removing duplicates, 17,661 passed onto the title/abstract review process. Subsequently, 634 studies were found to meet the inclusion criteria after the completion of abstract screening and were further screened for eligibility based on full-text assessment. Through the full-text screening, 588 studies were excluded due to the reported study type (reviews, conference abstracts), little relevance to the topic, limited outcomes of interest, limited data and not eligible geographical area. Hence, 45 studies were eventually considered in our systematic review. The flowchart of study selection and exclusion is presented in Figure 1.

Figure 1. PRISMA Flowchart of the screening process 
medRxiv preprint doi: https://doi.org/10.1101/2021.11.11.21266216; this version posted November 11, 2021. The copyright holder for this preprint (which was not certified by peer review) is the author/funder, who has granted medRxiv a license to display the preprint in perpetuity.

It is made available under a CC-BY-NC-ND 4.0 International license .

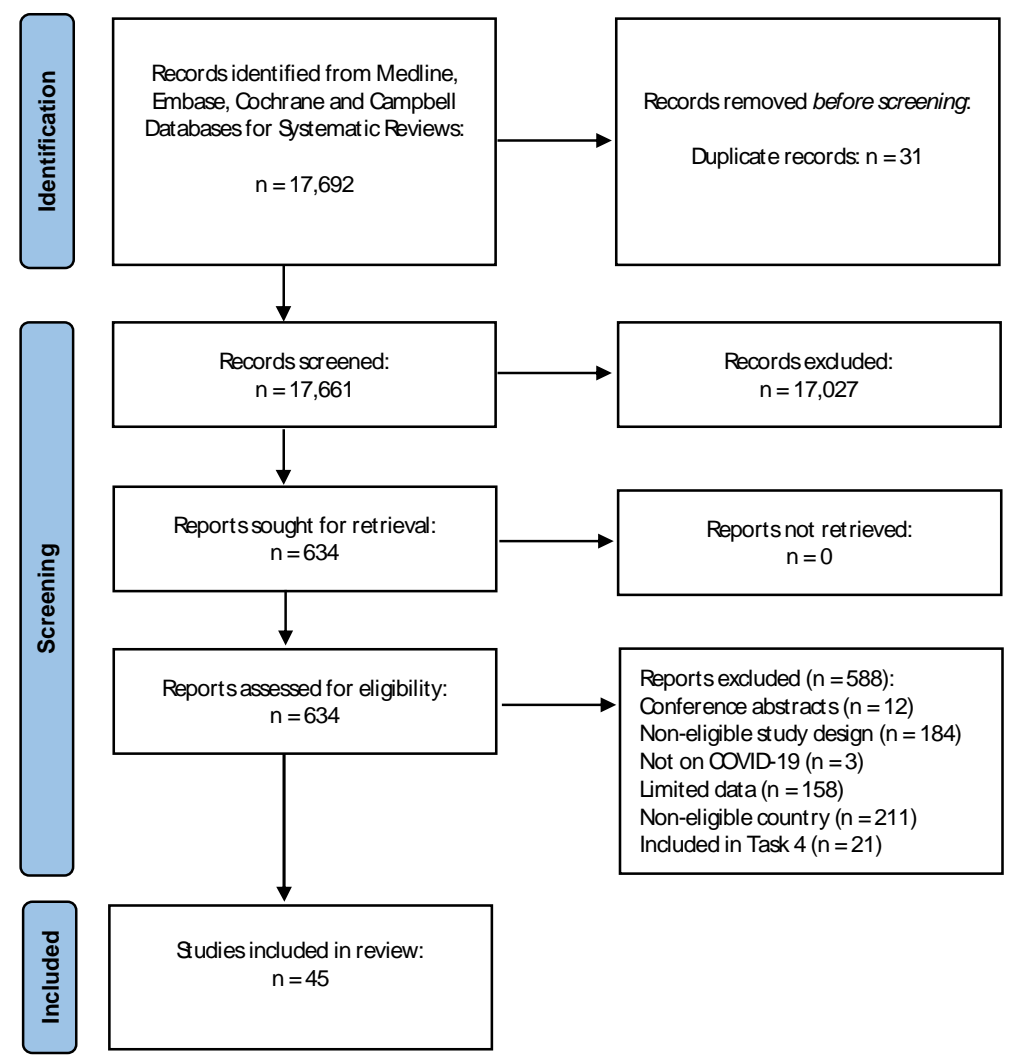

\section{Study Characteristics}

Among the 45 studies included in this current systematic review, 30 studies were modelling, one was an RCT, one followed a quasi-experimental approach, three were time series, three used a time-trend analysis, and seven were cohort studies. Concerning the type of NPI intervention, 40 studies evaluated different physical distancing measures, while 4 studies focused on case detection and contact tracing strategies and 3 on the implementation of hygiene measures. With regard to the geographical area, studies assessed data from Italy $(n=7)$, Spain $(n=3)$, England $(n=9)$, Scotland $(n=1)$, France $(n=3)$, Germany $(n=4)$, Portugal $(n=2)$, Greece $(n=1)$, Sweden ( $n=1)$, Denmark ( $n=2)$, Belgium $(n=2)$, Norway $(n=1)$ and the Netherlands $(n=1)$, while 8 studies considered multiple European countries in their analyses.

\section{Quality Appraisal}


medRxiv preprint doi: https://doi.org/10.1101/2021.11.11.21266216; this version posted November 11, 2021. The copyright holder for this preprint (which was not certified by peer review) is the author/funder, who has granted medRxiv a license to display the preprint in perpetuity.

It is made available under a CC-BY-NC-ND 4.0 International license .

Variability in study quality was noted in the 31 included modelling studies, but some patterns were also found. In several studies, there were concerns about the suitability of structural assumptions and parameters used given the multifactorial nature of interventions, their varying level of implementation and the inconsistent values published in the literature. Additionally, the investigation of uncertainty was either inadequate or not sufficiently reported in many studies. No study was excluded due to study quality; however, the results of our quality appraisal per included study are presented in detail in Supplementary

File 2.

\section{Combined physical distancing measures}

Overall, different combinations of physical distancing (SD) measures were investigated in terms of effectiveness in modelling and non-modelling approaches.; these are presented separately for ease of comparison due to heterogeneity in the implementation of NPIs across EU/UK/EEA countries, given the different combinations of applied measures, as well as the differences on the timeframes and the compliance of the general population, the results are presented per country to allow for internal comparisons.

\section{Italy}

\section{Modelling studies}

Four modelling studies were included in this current review with data from Italy. The effectiveness of lockdown measures implemented primarily in Lombardy and 15 northern provinces on March $3^{\text {rd }}, 2020$, and in the whole country afterwards (March $11^{\text {th }}, 2020$ ) was examined by Gatto et al. (11). Applying an SEIR model (Susceptible-Exposed-Infectious-Recovered), the authors parametrized data from 107 provinces between February $21^{\text {st }}$ and March $25^{\text {th }}, 2020$ and suggested that the SD measures reduced transmission by $45 \%$, while $0.226 \times 10^{6}$ cases were averted. Palladino et al. (12) showed that a 7-day earlier introduction of a lockdown across Italy would have averted 126,000 COVID-19 cases, 12,800 deaths, 54,700 non-ICU admissions and 15,600 ICU admissions in Italy, while Marzianoa et al. (13) within a SIR (SusceptibleInfectious-Recovered ) model simulated different scenarios for an earlier lifting of lockdowns, and concluding 
that an earlier lifting would have led to higher hospitalisation rates, as it was modelled that an earlier opening on May $4^{\text {th }}$ instead of May $18^{\text {th }}$, would lead to a twofold $(+118 \%)$ increase in the incidence of hospital admissions. This effect would be even more profound if the lockdown were to be lifted even earlier, on April $20^{\text {th }}$, with an increase in the incidence of hospitalisations $(+472 \%)$, while school closure would in parallel lead to a further reduction in cases. The investigation of the COVID-19 situation in Italy is complemented by the study of Sjodin et al. (14), who noted the significance of adherence to NPIs for the effective management of the pandemic in addition to the timing and duration.

\section{Non-Modelling studies}

Among the three non-modelling studies, Silverio et al. (15) found a strong positive relationship between the number of confirmed COVID-19 cases before lockdown and mortality up to 60 days later and between the daily incidence rate of new cases and mortality up to 60 days later. Timelli and Girardi (16), within the context of a retrospective study, also noted that the timing of lockdown measures is vital for the control of the spread, as regions with delayed implementation of lockdown measures had a higher peak of cases (382921 cases/100,000 vs, 265 cases $/ 100,000$ cases). Similarly, Lilleri et al. (17) pointed out that earlier implementation of lockdown measures, when the number of cases is still low, might contribute to the flattening of the pandemic curve. 


\begin{tabular}{|c|c|c|c|c|c|c|c|}
\hline \multirow{2}{*}{ First Author, Year } & \multirow{2}{*}{ Type of Study } & \multirow{2}{*}{ Time horizon } & \multirow{2}{*}{ Intervention(s) } & \multirow{2}{*}{ Comparator } & \multicolumn{3}{|c|}{ Results } \\
\hline & & & & & Cases & Deaths & Hospital/ICU admissions \\
\hline $\begin{array}{l}\text { Gatto et al. } 2020 \\
\text { (11) }\end{array}$ & SEIR model & $21 / 2-25 / 3 / 2020$ & $\begin{array}{l}9 / 3 / 2020 \text { lockdown in } \\
\text { Lombardy and } 15 \text { other } \\
\text { provinces which was } \\
\text { extended to the whole of } \\
\text { Italy on } 11 / 3 / 2020\end{array}$ & $\begin{array}{l}\text { Absence of SD } \\
\text { measures }\end{array}$ & $\begin{array}{l}\text { Absence of SD measures } \\
\left.\mathrm{R}_{0}=3.60 \text { ( } 95 \% \mathrm{Cl}: 3.49 \text { to } 3.84\right) \\
\text { Lockdown as of March } 25 \text { th, 2020 } \\
\downarrow \downarrow 45 \%(95 \% \mathrm{Cl}: 42 \text { to } 49 \%) \text { in } \\
\text { transmission } \\
0.226 \times 106 \text { (median) averted cases } \\
(95 \% \mathrm{Cl}: 0.172 \times 106 \text { to } 0.347 \times 106)\end{array}$ & & \\
\hline $\begin{array}{l}\text { Palladino et al. } \\
2020(12)\end{array}$ & $\begin{array}{l}\text { Modelling } \\
\text { study } \\
\text { (undefined) }\end{array}$ & $24 / 2-3 / 5 / 2020$ & $\begin{array}{l}\text { 7-day earlier lockdown } \\
(2 / 3 / 2020)\end{array}$ & $\begin{array}{l}\text { Lockdown as } \\
\text { implemented in Italy } \\
(9 / 3 / 2020)\end{array}$ & $\begin{array}{l}\text { Lockdown from } 9 / 3 / 2020 \\
210,717 \text { total cases } \\
\text { Lockdown from } 2 / 3 / 2020 \\
84,626 \text { total cases } \\
(-60 \%:-55 \% \text { to }-64 \%)\end{array}$ & $\begin{array}{l}\text { Lockdown from } 9 / 3 / 2020 \\
28,884 \text { total deaths } \\
\text { Lockdown from } 2 / 3 / 2020 \\
16,080 \text { total deaths } \\
(-44 \%:-38 \% \text { to }-50 \%)\end{array}$ & $\begin{array}{l}\text { Lockdown from } 9 / 3 / 2020 \\
105,359 \text { non-ICU admissions } \\
32,497 \text { ICU admissions } \\
\text { lockdown from } 2 / 3 / 2020 \\
50,644 \text { non-ICU admissions (-52\%:-46\% to -57\%) } \\
16,885 \text { ICU admissions (-48\%: }-42 \% \text { to - } 53 \%)\end{array}$ \\
\hline $\begin{array}{l}\text { Marzianoa et al. } \\
2021(13)\end{array}$ & SIR model & up to $30 / 9 / 2020$ & $\begin{array}{l}\text { 1) Lifting of lockdown on } \\
\text { 4/5/2020 } \\
\text { 2) Lifting of lockdown on } \\
\text { 27/4/2020 } \\
\text { 3) Lifting of lockdown on } \\
\text { 20/4/2020 }\end{array}$ & $\begin{array}{l}\text { Lifting of lockdown on } \\
18 / 5 / 2020\end{array}$ & & & $\begin{array}{l}\mathbf{1 8 / 5 / 2 0 2 0} \\
95,843(63,597-140,269) \text { cumulative hospitalised } \\
\text { cases } \\
\text { lockdown of } 4 / 5 / 2020 \\
\text { With schools closed } 110,764(71,637-168,761) \\
\text { With schools open } 514,625(216,832-1,049,453) \\
\text { lockdown of } 27 / 4 / 2020 \\
\text { With schools closed } 133,288(83,118-217,441) \\
\text { With schools open } 693,107(320,178-1,326,405) \\
\mathbf{2 0 / 4 / 2 0 2 0} \\
\text { With schools closed } 175,199(100,967-303,521) \\
\text { With schools open } 835,260(417,971-1,541,439)\end{array}$ \\
\hline $\begin{array}{l}\text { Sjodin et al. } 2020 \\
\text { (14) }\end{array}$ & SEIR model & 14-days period & $\begin{array}{l}\text { 1) Medium adherence to } \\
\text { community quarantine } \\
\text { 2) Complete adherence to } \\
\text { community quarantine }\end{array}$ & $\begin{array}{l}\text { Non-compliance to } \\
\text { community quarantine }\end{array}$ & $\begin{array}{l}\text { No adherence } \\
110 \text { secondary infections } \\
\text { Medium adherence } \\
70 \text { secondary infections } \\
\text { Complete adherence } \\
30 \text { secondary infections }\end{array}$ & & \\
\hline $\begin{array}{l}\text { Silverio et al., } \\
2020 \text { (15) }\end{array}$ & $\begin{array}{l}\text { Observational } \\
\text { study (cohort) }\end{array}$ & up to $3 / 5 / 2020$ & $\begin{array}{l}\text { Lockdown implemented in } \\
\text { Italy from } 9 / 3 / 2020\end{array}$ & N/A & $\begin{array}{l}\text { Positive correlation between } \\
\text { confirmed cases before lockdown and } \\
\text { mortality up to } 60 \text { days }(p<0.001 \text {, } \\
\text { R2 }=0.57)\end{array}$ & & \\
\hline $\begin{array}{l}\text { Timelli et al., } 2021 \\
\text { (16) }\end{array}$ & $\begin{array}{l}\text { Observational } \\
\text { study (cohort) }\end{array}$ & $24 / 2-11 / 5 / 2020$ & Lockdown & N/A & $\begin{array}{l}\text { Regions with delayed implementation } \\
\text { of lockdown measures had a higher } \\
\text { peak of cases ( } 382-921 \text { cases } / 100,000 \\
\text { vs, } 265 \text { cases } / 100,000 \text { cases) }\end{array}$ & & \\
\hline
\end{tabular}


苟

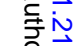

(1) 
medRxiv preprint doi: https://doi.org/10.1101/2021.11.11.21266216; this version posted November 11, 2021. The copyright holder for this preprint (which was not certified by peer review) is the author/funder, who has granted medRxiv a license to display the preprint in perpetuity.

It is made available under a CC-BY-NC-ND 4.0 International license .

282

\section{Spain}

\section{Modelling studies}

The SD measures implemented in Spain at the early stages of the pandemic were evaluated in two modelling studies. Hyafil et al. (18) predicted that $\mathrm{R}_{0}$ dropped from $5.89(5.46-7.0995 \% \mathrm{Cl})$ to $1.86(1.10-2.6395 \% \mathrm{Cl})$ after the declaration of a "state-of-emergency", while a further decrease to $0.48(0.15-1.1795 \% \mathrm{Cl})$ was noted after the implementation of a complete lockdown. With a similar SIR model, Casares \& Khan (19) showed that the timing of implementation plays a significant role in COVID-19 spread. Specifically, while the SD measures initiated on March 14th, 2020 (including mobility restrictions, school closure, socioeconomic activity suspensions, and home confinement) led to profound reductions of approximately $89-93 \%$ in the accumulated number of infections, as well as on the number of deaths and hospitalisations, the results would have been strengthened by a 4-day earlier enforcement.

\section{Non-Modelling studies}

The only non-modelling study identified for Spain was a time-series analysis performed by Santamaria $\boldsymbol{\&}$ Hortal (20), which indicated an early generalized decrease in the reproduction number after the nationwide lockdown. In contrast, the strengthening of the lockdown only had a low further impact, and an increase in Rt was related to the loosening of the lockdown measures. These results indicated the significance of a more generalized lockdown for COVID-19 spread to be contained, as well as the limited impact of a stricter lockdown.

Table 2. Study characteristics and results for modelling and non-modelling studies with data from Spain ( $n=3$ )

\begin{tabular}{|c|c|c|c|c|c|c|c|}
\hline \multirow[b]{2}{*}{ First Author, Year } & \multirow[b]{2}{*}{$\begin{array}{l}\text { Type of } \\
\text { Study }\end{array}$} & \multirow[b]{2}{*}{ Time horizon } & \multirow[b]{2}{*}{ Intervention(s) } & \multirow[b]{2}{*}{ Comparator } & \multicolumn{3}{|l|}{ Results } \\
\hline & & & & & Cases & Deaths & $\begin{array}{l}\text { Hospital/ICU } \\
\text { admissions }\end{array}$ \\
\hline $\begin{array}{l}\text { Hyafil et al., } 2021 \\
\text { (18) }\end{array}$ & SIR model & up to $15 / 4 / 2020$ & $\begin{array}{l}\text { 1) Emergency state } \\
\text { (March 16-30th and } \\
\text { April 13th-15th) } \\
\text { 2) Mandatory } \\
\text { confinement (March } \\
\text { 31st to April 12th) }\end{array}$ & $\begin{array}{l}\text { Absence of SD } \\
\text { measures (until } \\
\text { March 13th), }\end{array}$ & $\begin{array}{l}\text { Absence of SD } \\
\text { measures } \\
\text { RO=5.89: } 5.46-7.09 \\
\text { State of emergency } \\
R=1.86: 1.10-2.63 \\
\text { Lockdown } \\
R=0.48: 0.15-1.17\end{array}$ & & \\
\hline
\end{tabular}




\begin{tabular}{|c|c|c|c|c|c|c|c|}
\hline $\begin{array}{l}\text { Casares et al., } \\
2020(19)\end{array}$ & SIR model & $\begin{array}{l}29 / 01 / 2020 \\
\text { (Day } 1 \text { ) - 365- } \\
\text { day timeframe }\end{array}$ & $\begin{array}{l}\text { 1) } 14 / 3 / 2020 \\
\text { State of Alarm: } \\
\text { mobility restrictions, } \\
\text { school and } \\
\text { socioeconomic } \\
\text { activity suspensions, } \\
\text { and home } \\
\text { confinement } \\
\text { 2) 4-day earlier } \\
\text { implementation of } \\
\text { SoA }\end{array}$ & $\begin{array}{l}\text { Absence of SD } \\
\text { measures }\end{array}$ & $\begin{array}{l}\text { Absence of SD } \\
\text { measures } \\
46.95 \text { million } \\
\text { accumulated cases } \\
\text { State of Alarm: } \\
5 \text { million } \\
\text { accumulated cases } \\
(\downarrow 89,4 \%) \\
\text { if implemented 4 } \\
\text { days earlier } \\
1.65 \text { million } \\
\text { accumulated cases }\end{array}$ & $\begin{array}{l}\text { Absence of SD } \\
\text { measures } \\
\text { 400,000 deaths } \\
\text { State of Alarm: } \\
(\downarrow 89 \%) 42.5 \\
\text { thousand deaths } \\
\text { if implemented 4- } \\
\text { days earlier } \\
14,00 \text { deaths }\end{array}$ & $\begin{array}{l}\frac{\text { Absence of SD }}{\text { measures }} \\
2.4 \text { million people } \\
\text { State of Alarm: } \\
(\downarrow 93.5 \%) 155 \\
\text { thousand people } \\
\text { if implemented 4- } \\
\text { davs earlier } \\
44,300 \text { thousand } \\
\text { people }\end{array}$ \\
\hline $\begin{array}{l}\text { Santamaria \& } \\
\text { Hortal., } 2020(20)\end{array}$ & Time series & $14 / 3-20 / 5 / 2020$ & $\begin{array}{l}\text { Lockdown from } \\
15 / 3 / 2020 \text { up to } \\
11 / 5 / 2020\end{array}$ & N/A & $\begin{array}{l}\text { The lockdown is } \\
\text { associated to } \\
\text { decrease in Rt in the } \\
\text { whole dataset. }\end{array}$ & & \\
\hline
\end{tabular}

301

302

\section{United Kingdom}

\section{Modelling studies}

For the UK, five modelling studies were included in this review. Liu et al. (21) modelled the impact of the first 7-week national lockdown by using a Bayesian SEIR model to rebuild transmission dynamics. Estimations of Rt suggested that the SD measures, and particularly the implemented lockdown, effectively reduced COVID19 transmissibility and curbed the COVID-19 pandemic as the Rt was generally $<1$ during the period of lockdown. A more detailed approach concerning the effectiveness of specific measures was followed by Rice et al. (22), who indicated that the largest number of deaths could be prevented with the combination of case isolation, voluntary quarantine of contacts and physical distancing of those aged over 70. Notably, when school closure was also added in this set of measures, the number of deaths was projected to increase, which according to the authors, might be attributed to the failure of prioritizing the protection of the vulnerable population. An assessment of different scenarios which could follow the lifting of lockdown on May 8th, 2020, was reported by Goscé et al. (23), who concluded that although an extended lockdown would be highly effective, other measures, including shielding of older people, mass testing and facemask use could all synergistically lead to a reduction of cases and deaths. The authors suggested, the most effective strategy seemed to be a combination of weekly mass testing, contact tracing and facemask use, in parallel with lockdown, which was projected to reduce deaths by $48 \%$ compared with lockdown alone. The lockdown measures implemented in the second COVID-19 wave were studied by Davies et al. (24), who adjusted an age-structured mathematical model to estimate the effect of different lockdown types implemented in Northern Ireland and Wales in October 2020, as well as to make projections for various 
medRxiv preprint doi: https://doi.org/10.1101/2021.11.11.21266216; this version posted November 11, 2021. The copyright holder for this preprint (which was not certified by peer review) is the author/funder, who has granted medRxiv a license to display the preprint in perpetuity.

It is made available under a CC-BY-NC-ND 4.0 International license .

322 epidemiological scenarios up to March 31st, 2021. The findings showed a reduction of $35 \%$ (30-41) in Rt,

323 attributed to the Northern Ireland lockdown policy, and a $44 \%$ (37-49) decrease because of the lockdown in

324 Wales, both with schools closed. Also, from October 1st, 2020, to March 31st, 2021, a projected COVID-19

325 epidemic would result in 280,000 hospital admissions and 58,500 deaths without SD restrictions, but these

326 numbers could be reduced to 186,000 and 36,800 , respectively, with a 4-week lockdown with schools

327 remaining open. Closing schools was predicted to cause a further reduction in hospital admissions to

328157,000 and deaths by 30,300 . The authors concluded that a longer lockdown could reduce the number of

329 deaths but would fail to reduce peak pressure on hospital services. Supportive findings were published by

330 Yang et al. (25), who found that rolling interventions based on regional epidemiological data and with

331 varying durations and intensities should be an effective strategy to control COVIDQ19 outbreaks in the UK.

332 The authors suggested an intervention including suppression SD measures in London for 100 days and rolling

333 interventions for three weeks in other regions to reduce the overall number of infections and deaths.

$334 \quad$ Non-Modelling studies

335 In England, the second wave was managed with progressive SD measures, which led to a national lockdown

336 from November 5th to December 2nd, 2020, as presented in the study of Mensah et al. (2021) (26).

337 According to the timelines, infections rates were maintained low in the early summer period, while an

338 increase started from mid-August. The November lockdown contributed to the decrease in adult infection

339 rates, followed by declines in student cases with one week lag. From November 23rd 2020, cases in both

340 children and adults increased rapidly following the emergence of a more transmissible novel variant of

341 concern. The beneficial effect of SD measures in England was also confirmed through the time-series data of

342 Bernal et al. (27), who described the impact of physical distancing measures at week 13 of the COVID-19

343 pandemic. Timeline observations revealed a reduction in the number of outbreaks approximately three

344 weeks after the implementation of NPIs. However, the number of outbreaks remained high through week

345 18, implying a possibly limited or delayed impact of NPIs in residential areas. A decline in hospital/ICU

346 admissions and deaths started showing from weeks 14 and 15, respectively. 
Table 3. Study characteristics and results for modelling and non-modelling studies with data from the UK ( $n=7$ )

\begin{tabular}{|c|c|c|c|c|c|c|c|c|}
\hline \multirow[b]{2}{*}{$\begin{array}{l}\text { First Author, } \\
\text { Year }\end{array}$} & \multirow[b]{2}{*}{$\begin{array}{l}\text { Country, } \\
\text { Area/ } \\
\text { Population }\end{array}$} & \multirow[b]{2}{*}{ Study type } & \multirow[b]{2}{*}{ Time horizon } & \multirow[b]{2}{*}{ Intervention(s) } & \multirow[b]{2}{*}{ Comparator } & \multicolumn{3}{|c|}{ Results } \\
\hline & & & & & & Cases & Deaths & $\begin{array}{l}\text { Hospital/ICU } \\
\text { admissions }\end{array}$ \\
\hline $\begin{array}{l}\text { Davies et al., } \\
2021 \text { (24) }\end{array}$ & $\begin{array}{l}\text { England } \\
\text { (Northern } \\
\text { Ireland and } \\
\text { Wales) }\end{array}$ & $\begin{array}{l}\text { Age-structured } \\
\text { mathematical } \\
\text { model }\end{array}$ & $\begin{array}{l}01 / 03-13 / 10 / 2020 \\
\text { (projections up to } \\
31 / 3 / 2021 \text { ) }\end{array}$ & $\begin{array}{l}\text { 1) Northern Ireland's } \\
\text { lockdown: non-essential } \\
\text { retail remained open, } \\
\text { household bubbles of up to } \\
10 \text { people from } 2 \\
\text { households } \\
\text { 2) Wales' lockdown: non- } \\
\text { essential retail was closed, } \\
\text { stay at home, mixing with } \\
\text { individuals from outside } \\
\text { their households prohibited. } \\
\text { 3) School closure }\end{array}$ & $\begin{array}{l}\text { Absence of } \\
\text { SD measures }\end{array}$ & $\begin{array}{l}\text { Northern Ireland-type lockdown vs } \\
\text { Absence of SD measures } \\
\text { With schools closed: } \\
\downarrow 35 \% \text { (30-41) in Rt } \\
\text { With schools open: } \\
\downarrow 22 \% \text { (15-27) in Rt } \\
\text { Wales-type lockdown vs Absence } \\
\text { of SD measures } \\
\text { With schools closed: } \\
\downarrow 44 \%(37-49) \text { in Rt } \\
\text { With schools open: } \\
\downarrow 32 \%(25-39) \text { in Rt }\end{array}$ & $\begin{array}{l}\text { Absence of SD } \\
\text { measures } \\
58,500(55,800-61,100) \\
\text { Northern Ireland } \\
\text { With schools closed: } \\
34,900(33,500-36,700) \\
\text { With schools open: } \\
41,500(39,600-43,400) \\
\text { Wales } \\
\text { With schools closed: } \\
30,300(29,000-31,900) \\
\text { With schools open: } \\
36,800(34,900-38,800)\end{array}$ & $\begin{array}{l}\text { Absence of SD measures } \\
280,000(274,000- \\
287,000) \\
\text { Northern Ireland } \\
\text { With schools closed: } \\
177,000(171,000- \\
181,000) \\
\text { With schools open: } \\
206,000(199,000- \\
213,000) \\
\text { Wales } \\
\text { With schools closed: } \\
157,000(152,000- \\
163,000) \\
\text { With schools open: } \\
186,000(179,000- \\
193,000)\end{array}$ \\
\hline $\begin{array}{l}\text { Liu et al., } 2021 \\
(21)\end{array}$ & $\begin{array}{l}\text { England (9 } \\
\text { regions) }\end{array}$ & SEIR model & $27 / 2-31 / 5 / 2020$ & $\begin{array}{l}\text { National lockdown from } \\
\text { 23/3/2020 (lockdown } \\
\text { studied period: } 26 / 3- \\
\text { 10/5/2020) }\end{array}$ & $\begin{array}{l}\text { Before } \\
\text { lockdown } \\
\text { (control } \\
\text { period: } 12- \\
26 / 3 / 2020 \text { ) }\end{array}$ & $\begin{array}{l}\text { Before lockdown } \\
\text { R0 between } 2.8 \text { and } 3.9 \\
\text { After lockdown } \\
\text { Rt remained slightly }<1 \text { during most of } \\
\text { the lockdown period }\end{array}$ & & \\
\hline $\begin{array}{l}\text { Rice et al., } \\
2020 \text { (22) }\end{array}$ & $\begin{array}{l}\text { The UK and } \\
\text { Northern } \\
\text { Ireland }\end{array}$ & $\begin{array}{l}\text { IBMIC model } \\
\text { (Imperial's } \\
\text { model) }\end{array}$ & $\begin{array}{l}\text { The simulations } \\
\text { are for } 800 \text { days, } \\
\text { with day one } \\
\text { being } 1 / 1 / 2020 \text {. } \\
\text { The simulated } \\
\text { intervention } \\
\text { period is for } 91 \\
\text { days. }\end{array}$ & $\begin{array}{l}\text { 1) Home case isolation } \\
\text { 2) Voluntary home } \\
\text { quarantine } \\
\text { 3) SD for }>70 \text { years old } \\
\text { 4) SD for the entire } \\
\text { population } \\
\text { 5) School and uni closure }\end{array}$ & $\begin{array}{l}\text { Different } \\
\text { combinations } \\
\text { of } \\
\text { interventions }\end{array}$ & & $\begin{array}{l}\frac{\mathbf{5}}{4} 94-496 \text { total deaths } \\
\frac{\mathbf{1}}{4} 16 \text { total deaths } \\
\frac{\mathbf{1 + 2}}{355} \text { total deaths } \\
\frac{\mathbf{1 + 2 + 4}}{411-440} \text { total deaths } \\
\frac{\mathbf{1 + 4}}{347-402} \text { total deaths } \\
\frac{\mathbf{1 + 2 + 3}}{261-262} \text { total deaths } \\
\frac{\mathbf{1 + 2 + 3 + 5}}{342-357 \text { total deaths }}\end{array}$ & \\
\hline
\end{tabular}




\begin{tabular}{|c|c|c|c|c|c|c|c|c|}
\hline $\begin{array}{l}\text { Goscé et al., } \\
2020(23)\end{array}$ & $\begin{array}{l}\text { England, } \\
\text { London }\end{array}$ & $\begin{array}{l}\text { Modelling } \\
\text { study }\end{array}$ & $\begin{array}{l}\text { 30-day timeframe } \\
\text { from } 9 / 3 / 2020\end{array}$ & $\begin{array}{l}\text { Post lockdown lifting } \\
\text { scenarios (lockdown period: } \\
\text { 23/3- 8/5/2020): } \\
\text { 1) Universal testing + less } \\
\text { stringent SD measures } \\
\text { 2) Shielding those > } 60 \\
\text { years } \\
\text { 3) Universal testing + face } \\
\text { coverings use without a } \\
\text { lockdown. } \\
\text { 4) Universal testing, } \\
\text { isolation of infectious cases } \\
\text { and their contacts and use } \\
\text { of face coverings during } \\
\text { lockdown }\end{array}$ & Lift on $8 / 5$ & $\begin{array}{l}\text { Lift on } 8 / 5 \\
\mathrm{R} 0=2.56 \\
\text { Universal testing (weekly-3 } \\
\text { times/week) + less stringent SD } \\
\text { measures } \\
\mathrm{R}=1.87-2.07 \\
\text { Shielding those }>60 \text { years } \\
\mathrm{R}=3.07 \\
\text { Universal testing }+ \text { face coverings } \\
\text { use without a lockdown } \\
\mathrm{R}=1.92 \\
\text { Universal testing, isolation of } \\
\text { infectious cases and their contacts } \\
\text { and use of face coverings during } \\
\text { lockdown } \\
\mathrm{R}=0.27\end{array}$ & & \\
\hline $\begin{array}{l}\text { Yang et al., } \\
2021 \text { (25) }\end{array}$ & UK & & $\begin{array}{l}\text { February-April } \\
2020\end{array}$ & $\begin{array}{l}\text { 1) Suppression SD } \\
\text { measures (lockdown from } \\
23 / 3 / 2020 \text { ) } \\
\text { 2) Mitigation SD measures } \\
\text { (delay phase from 12-23/3) } \\
\text { 3) Rolling interventions }\end{array}$ & $\begin{array}{l}\text { Before SD } \\
\text { measures }\end{array}$ & $\begin{array}{l}\frac{\text { Suppression SD measures }}{(\text { lockdown from 23/3/2020) }} \\
\text { Before 23/3: R0=2.73 }[0.97-5.40] \\
\text { 28/3: Rt=0.69 }[0.59-0.79] \\
\text { Mitigation SD measures }(\mathbf{1 2 - 2 3 / 3 )} \\
\text { Before 23/3: R0 }=2.73[0.97-5.40] \\
\text { 27/5: Rt=0.98 }[95 \% \mathrm{Cl} 0.88-1.09] \\
\text { Rolling interventions } \\
\text { Before 23/3: } \mathrm{R} 0=2.73[0.97-5.40] \\
\text { 28/3: Rt=0.69 }[0.59-0.79]\end{array}$ & & \\
\hline $\begin{array}{l}\text { Mensah et al., } \\
2021 \text { (26) }\end{array}$ & England & $\begin{array}{l}\text { Observational } \\
\text { (time trend } \\
\text { analysis) }\end{array}$ & $\begin{array}{l}\text { July-December } \\
2020\end{array}$ & $\begin{array}{l}\text { Lockdown on } 5 / 11 / 2020 \\
\text { (schools remained open) }\end{array}$ & N/A & $\begin{array}{l}\text { The re-opening of schools after the } \\
\text { half-term break }(26 / 10 / 2020) \text { was } \\
\text { associated with a continuing increase } \\
\text { in infection rates across all } \\
\text { educational settings. } \\
\text { In adults, trends in SARS-CoV-2 } \\
\text { infection rates remained unchanged. } \\
\text { Following national lockdown in } \\
\text { November } 05 \text { th } 2020 \text {, cases in adults } \\
\text { plateaued and then fell rapidly. } \\
\text { Similar trends were observed in } \\
\text { secondary and primary educational } \\
\text { settings but with a one-week lag. }\end{array}$ & & \\
\hline $\begin{array}{l}\text { Bernal et al., } \\
2021(27)\end{array}$ & England & $\begin{array}{l}\text { Observational } \\
\text { (time trend } \\
\text { analysis) }\end{array}$ & $\begin{array}{l}\text { From the start of } \\
\text { the epidemic to } \\
\text { week } 18,2020\end{array}$ & $\begin{array}{l}\text { Mandatory social \& physical } \\
\text { distancing measures } \\
\text { implemented from week } 13\end{array}$ & $\mathrm{~N} / \mathrm{A}$ & Decline from week 16 & Decline from week 15 & $\begin{array}{l}\text { Decline from end of week } \\
14 \text { both hospital and ICU } \\
\text { admission rates }\end{array}$ \\
\hline
\end{tabular}


medRxiv preprint doi: https://doi.org/10.1101/2021.11.11.21266216; this version posted November 11, 2021. The copyright holder for this preprint (which was not certified by peer review) is the author/funder, who has granted medRxiv a license to display the preprint in perpetuity.

It is made available under a CC-BY-NC-ND 4.0 International license .

\section{France}

\section{Modelling studies}

For France, three modelling studies were included in this current review. The effect of lockdown as implemented in France (Île-de-France) was investigated by Di Domenico et al. (28) through a stochastic age-structured transmission model, concluding to an $81 \%$ reduction of the average number of contacts, which was projected to decrease R from $3.18(3.09,3.24)$ to $0.68(0.66,0.69)$. Further projections indicated that lifting lockdown without an exit strategy plan would unavoidably lead to a re-emergent situation. Moreover, the authors noted that the implementation of additional prolonged measures could delay the pandemic peak for at least two months and reduce the peak incidence by more than $80 \%$, but would not manage to relieve the healthcare system from the pressure of hospital and ICU admissions. An age-targeted analysis considering lockdown measures in France was performed by Roche et al. (29), who examined the implementation of lockdown strategies in particular age groups (i.e., 0-30, 30-60, >60), suggesting that either a complete lockdown or a partial one targeting young $(0-30)$ and middle-aged adults $(30-60)$ would be sufficient to achieve pandemic suppression, while indirectly decreasing mortality rates in older adults. They also found that a complete lockdown might prevent exhaustion in the healthcare system.

\section{$\underline{\text { Non-Modelling studies }}$}

The SD measures implemented for the second COVID-19 wave were assessed by Spaccaferri et al. (30) in 22 metropolitan areas of France within the context of an observational study. A significant decrease in the incidence of COVID-19 confirmed cases, as well as in the number of hospital admissions from 7 to 10 days after the lockdown was in place, suggesting that the measures possibly exerted a positive impact. 
medRxiv preprint doi: https://doi.org/10.1101/2021.11.11.21266216; this version posted November 11, 2021. The copyright holder for this preprint (which was not certified by peer review) is the author/funder, who has granted medRxiv a license to display the preprint in perpetuity.

It is made available under a CC-BY-NC-ND 4.0 International license .

Table 4. Study characteristics and results for modelling and non-modelling studies with data from France (n=3)

\begin{tabular}{|c|c|c|c|c|c|}
\hline \multirow{2}{*}{ Lead author, Year } & \multirow{2}{*}{ Study type } & \multirow{2}{*}{ Time horizon } & \multirow{2}{*}{ Intervention(s) } & \multirow{2}{*}{ Comparator } & Results \\
\hline & & & & & Cases \\
\hline $\begin{array}{l}\text { Di Domenico et al., } \\
2020(28)\end{array}$ & $\begin{array}{l}\text { Stochastic age- } \\
\text { structured } \\
\text { transmission } \\
\text { model }\end{array}$ & $\begin{array}{l}\text { 17/03- } \\
11 / 05 / 2020\end{array}$ & $\begin{array}{l}\text { Lockdown implemented in France } \\
\text { between } 17 / 03-11 / 05 / 2020\end{array}$ & $\begin{array}{l}\text { Absence of } \\
\text { SD } \\
\text { measures }\end{array}$ & $\begin{array}{l}\text { Absence of SD measures } \\
\text { RO= } 3.18(3.09,3.24) \\
\text { Lockdown } \\
R L D=0.68(0.66,0.69)\end{array}$ \\
\hline $\begin{array}{l}\text { Roche et al., } 2020 \\
\text { (29) }\end{array}$ & SEIR model & Undefined & $\begin{array}{l}\text { 1) Lockdown for all age groups } \\
\text { 2) Lockdown for those aged up to } \\
30 \\
\text { 3) Lockdown for those aged } 30-60 \\
\text { 4) Lockdown for those aged }>60\end{array}$ & $\begin{array}{l}\text { Absence of } \\
S D \\
\text { measures }\end{array}$ & $\begin{array}{l}\text { A complete lockdown and a partial strategy } \\
\text { targeting young and middle age classes were } \\
\text { the only interventions that could achieve } \\
\text { suppression. Focusing only on elderlies did not } \\
\text { dramatically change the epidemic duration. }\end{array}$ \\
\hline $\begin{array}{l}\text { Spaccaferri et al., } \\
2020(30)\end{array}$ & $\begin{array}{l}\text { Observational } \\
\text { (cohort) }\end{array}$ & $\begin{array}{l}\text { up to } \\
17 / 12 / 2020\end{array}$ & $\begin{array}{l}\text { Curfew from } 17 / 10 / 2020 \text {, lockdown } \\
\text { from } 30 / 10 / 2020 \text {, curfew from } \\
15 / 12 / 2020\end{array}$ & N/A & $\begin{array}{l}\text { The decrease was significant from } 7 \text { to } 10 \text { days } \\
\text { after lockdown implementation --> }-15.7 \text { to - } \\
20.6 \% \text { decrease in the incidence rate }\end{array}$ \\
\hline
\end{tabular}

\section{Germany}

\section{Modelling studies}

Aravindakshan et al. (31) studied the effectiveness of SD measures in Germany both from the perspectives of their implementation and lifting. Through a modified SEIR model, they found that if no SD measures were enforced, the number of cases would have a 24.6-fold (IQR: 20-29) rise. Moreover, if all SD measures and restrictions, taken into force between late February and early March, ended on April $21^{\text {st }}, 2020$, the daily number of cases would increase by $150 \%$ (IQR: $144-$ $156 \%$ ) and could be reduced to 108\% (IQR: 103.7-112.5\%) with a 1-week delay. The predictions also indicated that lifting non-essential services closures would cause the minimum increase in daily cases, followed by lifting initial business closures. Overall, it was shown that the maintenance of some NPIs in place for an additional week was associated with a decrease in COVID-19 cases by up to $20 \%$. The beneficial effect of SD measures introduced in Germany during the first wave was also highlighted in the modelling study of Schlosser et al. (32), who used mobility data to show that lockdown had a significant effect on COVID-19 transmission by flattening the pandemic curve and slowing down the spread to regions with a geographical distance. 
medRxiv preprint doi: https://doi.org/10.1101/2021.11.11.21266216; this version posted November 11, 2021. The copyright holder for this preprint (which was not certified by peer review) is the author/funder, who has granted medRxiv a license to display the preprint in perpetuity.

It is made available under a CC-BY-NC-ND 4.0 International license .

Non-Modelling studies

Wieland (33) conducted an interrupted time series to investigate the effectiveness of SD measures, which started from March 8th, 2020, with the cancellation of mass gatherings, followed by school closures on March 16th and a national lockdown announced March $23^{\text {rd }}$. Results showed a significant decrease of the daily growth rate from $22.8 \%(\mathrm{Cl}: 22.4,23.2])$ before any measure took place to $6.6 \%(\mathrm{Cl} 05.9,7.3)$ on March $10^{\text {th }}$. The second breakpoint was detected on March $26^{\text {th }}$ with a further reduction in daily growth from $6.8 \%$ to $1.9 \%(\mathrm{Cl} 1.7,2.0)$, and the third was noted on April $13^{\text {th }}$ when the daily growth rate shifted from $1.9 \%$ to $0.4 \%(\mathrm{Cl} 0.3,0.4)$. Additionally, the loosening of measures did not lead to a re-emergence of cases during the study period.

Table 5 Study characteristics and results for modelling and non-modelling studies with data from Germany (n=3)

\begin{tabular}{|c|c|c|c|c|c|}
\hline \multirow{2}{*}{$\begin{array}{c}\text { Lead author, } \\
\text { Year }\end{array}$} & \multirow{2}{*}{$\begin{array}{l}\text { Study } \\
\text { type }\end{array}$} & \multirow{2}{*}{ Time horizon } & \multirow{2}{*}{ Intervention(s) } & \multirow{2}{*}{ Comparator } & Results \\
\hline & & & & & Cases \\
\hline $\begin{array}{l}\text { Aravindakshan } \\
\text { et al., } 2020 \\
\text { (31) }\end{array}$ & $\begin{array}{l}\text { SEIR } \\
\text { model }\end{array}$ & $\begin{array}{l}18 / 02- \\
07 / 05 / 2020 \\
\text { and } 21 / 04- \\
19 / 07 / 2020\end{array}$ & $\begin{array}{l}\text { 1) SD measures: } \\
\text { contact } \\
\text { restrictions, initial } \\
\text { business closures, } \\
\text { retail outlet } \\
\text { closures, stay at } \\
\text { home orders, } \\
\text { non-essential } \\
\text { business closures, } \\
\text { closure of } \\
\text { educational } \\
\text { institutes, and } \\
\text { border closures } \\
\text { 2) Lifting SD } \\
\text { measures }\end{array}$ & $\begin{array}{l}\text { 1) Absence of } \\
\text { SD measures } \\
\text { 2) Keeping SD } \\
\text { measures in } \\
\text { place }\end{array}$ & 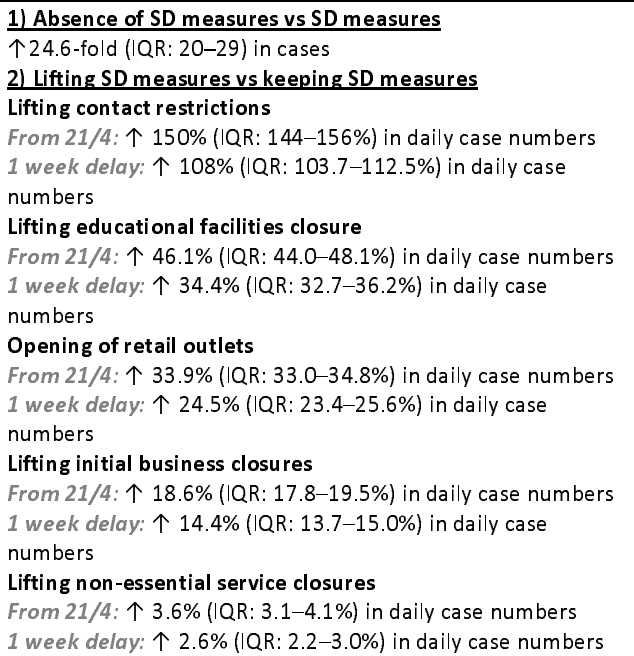 \\
\hline $\begin{array}{l}\text { Schlosser et } \\
\text { al., } 2020 \text { (32) }\end{array}$ & SIR model & $\begin{array}{l}\text { February- } \\
\text { June } 2020\end{array}$ & Lockdown & $\begin{array}{l}\text { Before } \\
\text { lockdown }\end{array}$ & $\begin{array}{l}\text { The lockdown } \\
\text { measures "flatten the curve" of the epidemic }\end{array}$ \\
\hline $\begin{array}{l}\text { Wieland et al., } \\
2020(33)\end{array}$ & $\begin{array}{l}\text { Time } \\
\text { series }\end{array}$ & $\begin{array}{l}15 / 2- \\
31 / 5 / 2020\end{array}$ & $\begin{array}{l}8 / 3 / 2020: \\
\text { cancellation of } \\
\text { mass events, } \\
\text { between } \\
\text { 16-18/3: closure } \\
\text { of schools } \\
23 / 3: \text { lockdown } \\
20 / 4 \text { : ease of SD } \\
\text { measures }\end{array}$ & N/A & $\begin{array}{l}\text { 1st breakpoint on 10/3 (Cl [March 09th, March 11th]) } \\
\text { Daily growth rate reduced from } 22.8 \%(0.228, \mathrm{Cl}[0.224,0.232]) \\
\text { to } 6.6 \%(0.066, \mathrm{Cl}[0.059,0.073]) \\
\text { 2nd breakpoint on } 26 / 3 \text { (Cl [March 25th, March } 27 \text { th]) } \\
\text { Decrease in daily growth from } 6.8 \% \text { to } 1.9 \%(0.019, \mathrm{Cl}[0.017, \\
0.020]) \text {. } \\
\text { 3rd breakpoint on } 13 / 4 \text { (Cl [April 12th, April 14th]) } \\
\text { Daily growth rate shifted from } 1.9 \% \text { to } 0.4 \%(0.004, \mathrm{Cl}[0.003 \text {, } \\
0.004])\end{array}$ \\
\hline
\end{tabular}


medRxiv preprint doi: https://doi.org/10.1101/2021.11.11.21266216; this version posted November 11, 2021. The copyright holder for this preprint (which was not certified by peer review) is the author/funder, who has granted medRxiv a license to display the preprint in perpetuity.

It is made available under a CC-BY-NC-ND 4.0 International license .

\section{Greece}

\section{Modelling studies}

In Greece, the SD measures implemented for the management of the first pandemic wave were evaluated through a SEIR model designed by Sypsa et al. (34). According to the results, the Rt was projected to decrease by $42.7 \%$ after the closure of schools, shops and entertainment venues and by $81.0 \%$, reaching 0.46 , after the implementation of a national lockdown. The authors also made an attempt to delineate each measure's impact concluding to an estimated reduction of approximately 1.1-1.3 in Rt if each measure was applied individually, and highlighted the significance of combining SD measures to strengthen the overall effectiveness.

Table 1. Study characteristics and results for modelling and non-modelling studies with data from Greece ( $n=1)$

\begin{tabular}{|c|c|c|c|c|c|}
\hline \multirow{2}{*}{$\begin{array}{c}\text { Lead author, } \\
\text { Year }\end{array}$} & \multirow{2}{*}{$\begin{array}{l}\text { Study } \\
\text { type }\end{array}$} & \multirow{2}{*}{ Time horizon } & \multirow{2}{*}{ Intervention(s) } & \multirow{2}{*}{ Comparator } & Results \\
\hline & & & & & Cases \\
\hline $\begin{array}{c}\text { Sypsa et al., } \\
2021 \text { (34) }\end{array}$ & $\begin{array}{l}\text { SEIR } \\
\text { model }\end{array}$ & $\begin{array}{c}15 / 2- \\
26 / 4 / 2020\end{array}$ & $\begin{array}{l}\text { 1) } 11-22 / 3 / 2020 \text { : closure of } \\
\text { schools, entertainment } \\
\text { venues, and shops } \\
\text { 2) } 23 / 3-26 / 4 / 2020 \text { : national } \\
\text { lockdown }\end{array}$ & $\begin{array}{l}\text { Before SD } \\
\text { measures }\end{array}$ & 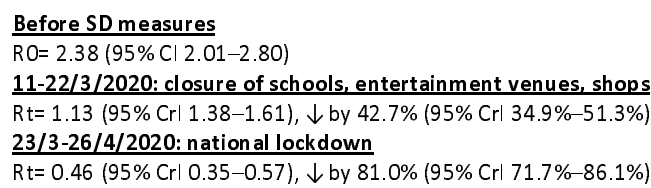 \\
\hline
\end{tabular}

\section{Portugal}

\section{$\underline{\text { Modelling studies }}$}

In Portugal, a modelling study by Ricoca Peixoto et al. (35) forecasted 5568 averted cases, 146 averted deaths, and 519 averted ICU admissions between April $1^{\text {st }}$ to $15^{\text {th }}, 2020$, after the lockdown implemented on March $16^{\text {th }}, 2020$. Among the contributing factors of the effectiveness of the SD measures, Pais \& Taveira (36) focused on the level of population compliance and designed a simple SI model parameterized with data from the population of Portugal. Simulations showed that the benefit of pandemic mitigation increases with increasing population adherence to the control measures. However, as the authors stated, percentages of compliance over $75 \%$ might 
medRxiv preprint doi: https://doi.org/10.1101/2021.11.11.21266216; this version posted November 11, 2021. The copyright holder for this preprint (which was not certified by peer review) is the author/funder, who has granted medRxiv a license to display the preprint in perpetuity.

It is made available under a CC-BY-NC-ND 4.0 International license .

probably require a prolonged implementation period, which can result in economic/social burden, implying the multifactorial nature of SD measures.

Table 7. Study characteristics and results for modelling studies with data from Portugal (n=2)

\begin{tabular}{|c|c|c|c|c|c|c|c|}
\hline \multirow{2}{*}{$\begin{array}{c}\text { Lead Author, } \\
\text { Year }\end{array}$} & \multirow{2}{*}{$\begin{array}{l}\text { Study } \\
\text { type }\end{array}$} & \multirow[b]{2}{*}{ Time horizon } & \multirow[b]{2}{*}{ Intervention(s) } & \multirow[b]{2}{*}{ Comparator } & \multicolumn{3}{|c|}{ Results } \\
\hline & & & & & Cases & Deaths & $\begin{array}{l}\text { Hospital/ICU } \\
\text { admissions }\end{array}$ \\
\hline $\begin{array}{l}\text { Ricoca } \\
\text { Peixoto et al., } \\
2020 \text { (35) }\end{array}$ & $\begin{array}{l}\text { ARIMA } \\
\text { models } \\
\text { (AutoReg } \\
\text { ressive } \\
\text { Integrate } \\
\text { d Moving } \\
\text { Average) }\end{array}$ & $\begin{array}{l}\text { up to } \\
15 / 4 / 2020\end{array}$ & $\begin{array}{l}\text { Lockdown from } \\
16 / 3 / 2020\end{array}$ & $\begin{array}{l}\text { Absence of } \\
\text { lockdown }\end{array}$ & $\begin{array}{l}\frac{\text { Absence of }}{\text { lockdown }} \\
24,405 \text { cases } \\
\text { After lockdown } \\
\begin{array}{l}(1-15 / 4 / 2020) \\
5568 \text { averted }\end{array} \\
\text { cases }(-23 \% \text {, } \\
n=18,837)\end{array}$ & $\begin{array}{l}\frac{\text { Absence of }}{\text { lockdown }} \\
588 \text { deaths } \\
\frac{\text { After }}{\text { lockdown (1- }} \\
\frac{15 / 4 / 2020)}{146 \text { averted }} \\
\text { deaths }(-25 \%, \\
n=442)\end{array}$ & $\begin{array}{l}\frac{\text { Absence of }}{\text { lockdown }} \\
748 \text { ICU admissions } \\
\text { After lockdown (1- } \\
\text { 15/4/2020) } \\
\text { 519 averted deaths } \\
(-69 \%, n=229)\end{array}$ \\
\hline $\begin{array}{l}\text { Pais \& Taveira } \\
\text { et al., } 2020 \\
\text { (36) }\end{array}$ & SI model & $\begin{array}{l}\text { up to } \\
19 / 8 / 2020\end{array}$ & $\begin{array}{l}\text { SD measure } \\
\text { compliance } \\
\text { scenarios }\end{array}$ & $\begin{array}{l}\text { Absence of } \\
\text { measures }\end{array}$ & $\begin{array}{l}\frac{30-40 \%}{\text { compliance }} \\
885,725-928,703 \\
\text { total cases } \\
\frac{70-75 \%}{\text { compliance }} \\
456,446- \\
572,624 \text { total } \\
\text { cases } \\
\text { 90\% compliance } \\
847 \text { total cases }\end{array}$ & $\begin{array}{l}\frac{30-40 \%}{\text { compliance }} \\
14,674- \\
16,754 \text { total } \\
\text { deaths } \\
\frac{70-75 \%}{\text { compliance }} \\
5,288-9,056 \\
\text { total deaths } \\
\text { 90\% } \\
\text { compliance } \\
23 \text { total } \\
\text { deaths }\end{array}$ & \\
\hline
\end{tabular}

\section{Sweden}

\section{Modelling studies}

Considering the COVID-19 situation in Sweden, Sjodin et al. (37) developed a SEIR model to examine different combinations of SD measures. The analysis revealed that the implementation of moderate SD measures in ages 0-59 years, alongside strong SD measures in ages over 60 years, and effective detection and isolation of infectious individuals would lead to the most significant reduction in infected cases and infection fatality rate. However, the authors concluded that although ICU demand could be maintained at non-overwhelming levels for the healthcare system with mitigation strategies, deaths are not able to be effectively prevented. 
medRxiv preprint doi: https://doi.org/10.1101/2021.11.11.21266216; this version posted November 11, 2021. The copyright holder for this preprint (which was not certified by peer review) is the author/funder, who has granted medRxiv a license to display the preprint in perpetuity.

It is made available under a CC-BY-NC-ND 4.0 International license .

Table 8. Study characteristics and results for modelling studies with data from Sweden ( $n=1$ )

\begin{tabular}{|c|c|c|c|c|c|c|}
\hline \multirow{2}{*}{$\begin{array}{l}\text { Lead author, } \\
\text { Year }\end{array}$} & \multirow{2}{*}{$\begin{array}{l}\text { Study } \\
\text { type }\end{array}$} & \multirow[b]{2}{*}{ Time horizon } & \multirow[b]{2}{*}{ Intervention(s) } & \multirow[b]{2}{*}{ Comparator } & \multicolumn{2}{|c|}{ Results } \\
\hline & & & & & Cases & Deaths \\
\hline $\begin{array}{l}\text { Sjodin et } \\
\text { al., } 2020 \\
\text { (37) }\end{array}$ & $\begin{array}{l}\text { SEIR } \\
\text { model }\end{array}$ & $\begin{array}{l}24 / 2- \\
1 / 9 / 2020\end{array}$ & $\begin{array}{l}\text { 1) Modest SD in ages } 0-59 \\
\text { years, moderate in ages }>60 \\
\text { years } \\
\text { 2) Modest SD in ages } 0-59 \\
\text { years, moderately strong in ages } \\
>60 \text { years } \\
\text { 3) Moderate SD in ages } 0-59 \\
\text { years, very strong in ages } 60-79 \\
\text { years, strong in ages }>80 \text { years, } \\
\text { and } \\
\text { increased isolation of cases } \\
\text { 4) Moderate SD in ages } 0-59 \\
\text { years, strong in ages } 60+\text { years, } \\
\text { and further improved isolation } \\
\text { of cases }\end{array}$ & $\begin{array}{l}\text { Absence of } \\
\text { SD } \\
\text { measures }\end{array}$ & 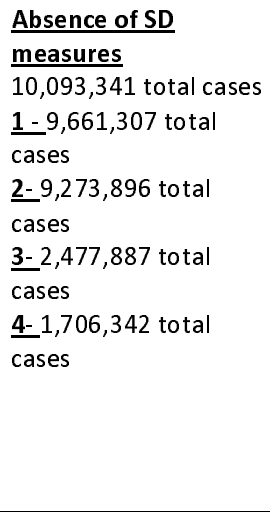 & $\begin{array}{l}\text { Absence of SD } \\
\frac{\text { measures }}{\mathrm{IFR}=0.46} \\
\underline{\mathbf{1}} \mathrm{IFR}=0.45 \\
\underline{\mathbf{2}} \mathrm{IFR}=0.42 \\
\underline{\mathbf{3}} \mathrm{IFR}=0.35 \\
\underline{\mathbf{4}} \mid \mathrm{FR}=0.30\end{array}$ \\
\hline
\end{tabular}

\section{Denmark}

\section{Modelling studies}

Valentin et al. (38) identified the basic reproduction number in Denmark before and after the lockdown enforcement with the design of a SEIR-type model, showing a significant reduction from

3.32 (95\% PI: 3.31-3.33) to 0.92(95\% PI: 0.92-0.93).

Table 9. Study characteristics and results for modelling studies with data from Denmark ( $n=1)$

\begin{tabular}{|c|c|c|c|c|c|c|}
\hline & & & & & & Results \\
\hline $\begin{array}{c}\text { Lead Author, } \\
\text { Year }\end{array}$ & $\begin{array}{l}\text { Country, Area/ } \\
\text { Population }\end{array}$ & $\begin{array}{l}\text { Study } \\
\text { type }\end{array}$ & Time horizon & Intervention(s) & Comparator & Cases \\
\hline $\begin{array}{l}\text { Valentin et } \\
\text { al., } 2021(38)\end{array}$ & Denmark & $\begin{array}{c}\text { SEIR } \\
\text { model }\end{array}$ & $\begin{array}{c}16 / 3- \\
13 / 4 / 2020\end{array}$ & Lockdown from $18 / 3 / 2020$ & $\begin{array}{c}\text { Before } \\
\text { lockdown }\end{array}$ & $\begin{array}{l}\text { Before lockdown } \\
\text { Ro }=3.32(95 \% \mathrm{PI}: 3.31-3.33) \\
\mathbf{2 8} \text { days after lockdown } \\
\mathrm{Rt}=0.92(95 \% \mathrm{PI}: 0.92-0.93)\end{array}$ \\
\hline
\end{tabular}

\section{Belgium}

\section{$\underline{\text { Non-Modelling studies }}$}

Ingelbeen et al. (39) assessed the influence of progressive lifting and re-enforcement of SD measures in Brussels during the second wave of the pandemic between August and November 2020. During the summer of 2020 , an outburst in the number of cases in the second largest city 
medRxiv preprint doi: https://doi.org/10.1101/2021.11.11.21266216; this version posted November 11, 2021. The copyright holder for this preprint (which was not certified by peer review) is the author/funder, who has granted medRxiv a license to display the preprint in perpetuity.

It is made available under a CC-BY-NC-ND 4.0 International license .

forced strict physical distancing measures, which, however, were loosened after holidays despite the rising number of cases. From October 6th, 2020, SD measures started progressively to be reintroduced, and Rt, which peaked on September 17th, 2020, at 1.48 (95\% Crl:1.35-1.63), decreased by $44.6 \%$ to 0.82 (95\% Crl: $0.79-0.85)$ three weeks post to the closure of restaurants, bars, and sports facilities.

Table 10. Study characteristics and results for non-modelling studies with data from Belgium ( $n=1)$

\begin{tabular}{|l|l|l|l|l|l|}
\hline $\begin{array}{c}\text { Lead Author, } \\
\text { Year }\end{array}$ & $\begin{array}{l}\text { Country, Area/ } \\
\text { Population }\end{array}$ & Study type & Time horizon & Intervention(s) & Comparator \\
\hline $\begin{array}{l}\text { Ingelbeen et } \\
\text { al., 2021 (39) }\end{array}$ & Brussels & $\begin{array}{l}\text { Observational } \\
\text { study (time } \\
\text { trend } \\
\text { analysis) }\end{array}$ & $\begin{array}{l}\text { August- } \\
\text { November } \\
2020\end{array}$ & $\begin{array}{l}\text { From 6/8/2020, SD } \\
\text { measures went into force } \\
\text { progressively, including the } \\
\text { closure of bars, cafes, } \\
\text { restaurants and sports } \\
\text { facilities, teleworking, } \\
\text { restrictions in private } \\
\text { gatherings, curfew }\end{array}$ & $\begin{array}{l}\mathrm{N} / \mathrm{A} \\
\text { 1.63) on } 17 / 9 / 2020 . \text { Three } \\
\text { weeks after the closure of } \\
\text { bars, restaurants and sports } \\
\text { facilities, Rt had decreased } \\
\text { by } 44.6 \% \text { to 0.82 (95\% Crl: } \\
0.79-0.85)\end{array}$ \\
\hline
\end{tabular}

\section{Multiple Countries}

\section{Modelling studies}

Consistently with the studies performed in each country, the reduction in COVID-19 transmission was also confirmed by Gul et al. (40) for Germany and Italy, who studied both countries up to April $16^{\text {th }}, 2020$. It was observed that with the adoption of strict interventions, there would be a reduction of $R_{0}$ from 2.8-3.0 to 1.3-1.5. The beneficial effect of SD was also profound in the studies of Bryant et al. (41) and Belloir et al. (42), who predicted reductions in Rt in all studied countries, except for Sweden and Denmark. Concerning the timing of implementation, Palladino et al. (43) indicated that the daily number of cases would have been reduced by $92 \%, 81 \%, 78 \%$ and $90 \%$ in France, Italy, Spain and the UK, respectively, if in each country the lockdown had been implemented earlier, three days after the first- 50 cases, and not at the time of enactment. 
medRxiv preprint doi: https://doi.org/10.1101/2021.11.11.21266216; this version posted November 11, 2021. The copyright holder for this preprint (which was not certified by peer review) is the author/funder, who has granted medRxiv a license to display the preprint in perpetuity.

It is made available under a CC-BY-NC-ND 4.0 International license .

\section{$\underline{\text { Non-Modelling studies }}$}

A more generic analysis was performed by Khataee et al. (44), who used data from nine European countries, including Italy, Spain, France, the UK, Germany, Switzerland, Netherlands, Belgium and Sweden, to quantitatively determine the impact of SD measures as implemented in each one of these countries through mobility data. The results indicated a drop in $R_{0}$ in all studied countries, while a strong positive correlation between the decrease in the $\mathrm{R}$ and the mobility restrictions was also found. Moreover, the time between the peak of cases and the SD measures initiation was irreversibly associated with the stringency of measures. In more specific, the time from the national lockdown to the peak varied from 10 days in Italy to more than three weeks in Switzerland, whereas the time from mobility change to the peak ranged from 19 days in Italy and Spain up to 34 days in Sweden. Similar conclusions arise from the interrupted time series analysis of Voko \& Pitter (45) in 28 European countries showing that the incidence of new COVID-19 cases, which grew by $24 \%$ on average daily before the change point, reduced in a range from $0.9 \%$ to $1.7 \%$ by increasing SD measures.

The impact of different lockdown durations was studied by Coccia (46) with a case series of six European countries, including Austria, France, Italy, Portugal, Spain, and Sweden, which were grouped under the categories of those with a 15-day duration of lockdown and those with a 61day duration. Results suggested that countries with longer national lockdown duration had a higher fatality rate, while differences in COVID-19 cases were not significant. The authors attributed the increased fatality rate possibly to lower healthcare capacities and older populations forcing countries to maintain lockdown measures for more extended periods. Finally, MartinezValero et al. (47) indicated a significant direct correlation between the number of deaths and the time elapsed from the declaration of the initial case to the introduction of lockdown decision during the COVID-19 pandemic in 16 European countries. 
medRxiv preprint doi: https://doi.org/10.1101/2021.11.11.21266216; this version posted November 11, 2021. The copyright holder for this preprint (which was not certified by peer review) is the author/funder, who has granted medRxiv a license to display the preprint in perpetuity.

It is made available under a CC-BY-NC-ND 4.0 International license .

Table 12. Study characteristics and results for modelling and non-modelling studies, which included data from multiple countries $(n=6)$

\begin{tabular}{|c|c|c|c|c|c|c|c|}
\hline \multirow{2}{*}{$\begin{array}{c}\text { Lead } \\
\text { Author, } \\
\text { Year }\end{array}$} & \multirow{2}{*}{$\begin{array}{c}\text { Country, } \\
\text { Area/ } \\
\text { Population }\end{array}$} & \multirow{2}{*}{$\begin{array}{l}\text { Study } \\
\text { type }\end{array}$} & \multirow{2}{*}{$\begin{array}{c}\text { Time } \\
\text { horizon }\end{array}$} & \multirow{2}{*}{$\begin{array}{c}\text { Interventi } \\
\text { on/s }\end{array}$} & \multirow{2}{*}{$\begin{array}{c}\text { Compar } \\
\text { ator }\end{array}$} & \multicolumn{2}{|c|}{ Results } \\
\hline & & & & & & Cases & Deaths \\
\hline $\begin{array}{l}\text { Gul et al., } \\
2020(40)\end{array}$ & $\begin{array}{l}\text { Germany, } \\
\text { Italy }\end{array}$ & $\begin{array}{l}\text { Monte } \\
\text { Carlo }\end{array}$ & $\begin{array}{l}\text { up to } \\
16 / 4 / 20 \\
20\end{array}$ & $\begin{array}{l}\text { SD } \\
\text { measures, } \\
\text { school } \\
\text { closure } \\
\text { and } \\
\text { workplace } \\
\text { restriction } \\
\text { s }\end{array}$ & $\begin{array}{l}\text { Absence } \\
\text { of } S D \\
\text { measure } \\
s\end{array}$ & 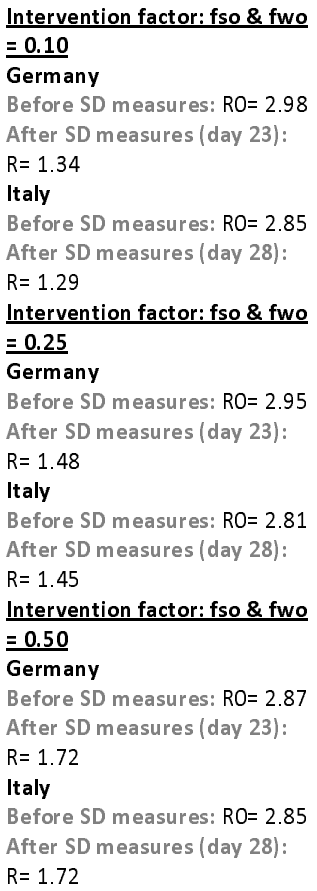 & \\
\hline $\begin{array}{l}\text { Palladino } \\
\text { et al., } \\
2020 \text { (43) }\end{array}$ & $\begin{array}{l}\text { France, } \\
\text { Italy, Spain, } \\
\text { and the UK }\end{array}$ & $\begin{array}{l}\text { Modelli } \\
\text { ng }\end{array}$ & $\begin{array}{l}23 / 1- \\
15 / 8 / 20 \\
20\end{array}$ & $\begin{array}{l}\text { Earlier } \\
\text { lockdown } \\
\text { implemen } \\
\text { tation: } \\
25 / 2 \text { for } \\
\text { Italy, } 2 / 3 \\
\text { for } \\
\text { France, } \\
3 / 3 \text { for } \\
\text { Spain, and } \\
6 / 3 \text { for } \\
\text { the UK }\end{array}$ & $\begin{array}{l}\text { Lockdow } \\
\mathrm{n} \text { as } \\
\text { impleme } \\
\text { nted in } \\
\text { each } \\
\text { country }\end{array}$ & & $\begin{array}{l}\text { Lockdown as implemented (deaths } \\
\text { as of } 15 / 8 \text { ) } \\
\text { France: } 31,174 \\
\text { Italy: } 35,449 \\
\text { Spain: } 30,731 \\
\text { UK: } 41,361 \\
\text { Earlier lockdown (deaths as of } 15 / 8 \text { ) } \\
\text { France: } 2461 \text { ( } 95 \% \mathrm{Cl}: 1440 \text { to } 4272 \text { ), } \\
\downarrow 92 \% \text { ( } 95 \% \mathrm{Cl}: 86 \% \text { to } 95 \%) \\
\text { It aly: } 6769(95 \% \mathrm{Cl}: 5652 \text { to } 8135), \downarrow \\
81 \%(95 \% \mathrm{Cl}: 77 \% \text { to } 84 \%) \\
\text { Spain: } 6792(95 \% \mathrm{Cl}: 4154 \text { to } 11525 \text { ), } \\
\downarrow 78 \% \text { (95\% Cl: } 62 \% \text { to } 86 \%) \\
\text { UK: } 4071(95 \% \mathrm{Cl}: 3281 \text { to } 5067), \downarrow \\
90 \%(95 \% \mathrm{Cl}: 88 \% \text { to } 92 \%)\end{array}$ \\
\hline
\end{tabular}


medRxiv preprint doi: https://doi.org/10.1101/2021.11.11.21266216; this version posted November 11, 2021. The copyright holder for this preprint (which was not certified by peer review) is the author/funder, who has granted medRxiv a license to display the preprint in perpetuity.

It is made available under a CC-BY-NC-ND 4.0 International license .

\begin{tabular}{|c|c|c|c|c|c|c|c|}
\hline $\begin{array}{l}\text { Khataee } \\
\text { et al., } \\
2021(44)\end{array}$ & $\begin{array}{l}\text { Italy, Spain, } \\
\text { France, UK, } \\
\text { Germany, } \\
\text { Switzerland, } \\
\text { Netherlands } \\
\text {, Belgium } \\
\text { and Sweden }\end{array}$ & $\begin{array}{l}\text { Observ } \\
\text { ational } \\
\text { (cohort } \\
\text { ) }\end{array}$ & $\begin{array}{l}90 \text {-day } \\
\text { period } \\
\text { starting } \\
\text { from } \\
13 / 01 / 2 \\
020\end{array}$ & $\begin{array}{l}\text { SD } \\
\text { measures } \\
\text { as } \\
\text { implemen } \\
\text { ted in } \\
\text { each } \\
\text { country }\end{array}$ & $\begin{array}{l}\text { Before } \\
S D \\
\text { measure } \\
\mathrm{s}\end{array}$ & $\begin{array}{l}\text { Before SD measures } \\
\text { Italy: RO }=3.52 \pm 0.08 \\
\text { Spain: } \mathrm{RO}=3.54 \pm 0.06 \\
\text { France: } \mathrm{RO}=3.22 \pm 0.06 \\
\text { Great Britain: } \mathrm{RO}=3.24 \pm 0.06 \\
\text { Germany: } \mathrm{RO}=3.00 \pm 0.06 \\
\text { Belgium: } \mathrm{RO}=3.04 \pm 0.06 \\
\text { Netherlands: } \mathrm{RO}=3.16 \pm 0.04 \\
\text { Switzerland: } \mathrm{RO}=2.88 \pm 0.10 \\
\text { Sweden: } \mathrm{RO}=2.40 \pm 0.06 \\
\text { After SD measures } \\
\text { Italy: } \mathrm{RO}=0.68 \pm 0.01 \\
\text { Spain: } \mathrm{RO}=0.54 \pm 0.03 \\
\text { France: } \mathrm{RO}=0.42 \pm 0.01 \\
\text { Great Britain: } \mathrm{RO}=0.70 \pm 0.01 \\
\text { Germany: } \mathrm{RO}=0.54 \pm 0.01 \\
\text { Belgium: } \mathrm{RO}=0.44 \pm 0.01 \\
\text { Netherlands: } \mathrm{RO}=0.48 \pm 0.01 \\
\text { Switzerland: } \mathrm{RO}=0.36 \pm 0.02 \\
\text { Sweden: } \mathrm{RO}=0.82 \pm 0.01\end{array}$ & \\
\hline $\begin{array}{l}\text { Belloir et } \\
\text { al., } 2021 \\
(42)\end{array}$ & $\begin{array}{l}\text { Germany, } \\
\text { Spain, Italy, } \\
\text { France }\end{array}$ & $\begin{array}{l}\text { Modelli } \\
\text { ng }\end{array}$ & $\begin{array}{l}\text { up to } \\
08 / 05 / 2 \\
020\end{array}$ & $\begin{array}{l}\text { SD } \\
\text { measures } \\
\text { as } \\
\text { implemen } \\
\text { ted in } \\
\text { each } \\
\text { country }\end{array}$ & $\begin{array}{l}\text { Before } \\
\text { lockdow } \\
n\end{array}$ & $\begin{array}{l}\text { Before lockdown } \\
\text { Germany: } \mathrm{RO}=4.5 \\
\text { Spain: } \mathrm{RO}=7 \\
\text { Italy: } \mathrm{RO}=4.1 \\
\text { France: } \mathrm{RO}=3.6 \\
\text { After lockdown (08/05/2020) } \\
\text { Germany: } \mathrm{Rt}=0.84 \\
\text { Spain: } \mathrm{Rt}=0.57 \\
\text { Italy: } \mathrm{Rt}=0.81 \\
\text { France: } \mathrm{Rt}=0.68\end{array}$ & \\
\hline $\begin{array}{l}\text { Bryant et } \\
\text { al., } 2020 \\
\text { (41) }\end{array}$ & $\begin{array}{l}\text { Austria, } \\
\text { Belgium, } \\
\text { Denmark, } \\
\text { France, } \\
\text { Germany, } \\
\text { Italy, } \\
\text { Norway, } \\
\text { Spain, } \\
\text { Sweden, } \\
\text { Switzerland, } \\
\text { UK }\end{array}$ & $\begin{array}{l}\text { MCMC } \\
\text { model }\end{array}$ & $\begin{array}{l}\text { Data up } \\
\text { to } \\
29 / 3 / 20 \\
20, \\
\text { forecast: } \\
30 / 3- \\
19 / 4 / 20 \\
20\end{array}$ & $\begin{array}{l}\text { SD } \\
\text { measures } \\
\text { as } \\
\text { implemen } \\
\text { ted in } \\
\text { each } \\
\text { country }\end{array}$ & $\begin{array}{l}\text { Before } \\
\text { SD } \\
\text { measure } \\
\mathrm{s}\end{array}$ & $\begin{array}{l}\text { Before SD measures } \\
\text { Austria: } \mathrm{RO}=3.11 \\
\text { Belgium: } \mathrm{RO}=3.24 \\
\text { Denmark: } \mathrm{RO}=3.02 \\
\text { France: } \mathrm{RO}=2.91 \\
\text { Germany: } \mathrm{RO}=3.08 \\
\text { Italy: } \mathrm{RO}=3.17 \\
\text { Norway: } \mathrm{RO}=2.82 \\
\text { Spain: } \mathrm{RO}=3.19 \\
\text { Sweden: } \mathrm{RO}=2.89 \\
\text { Switzerland: } \mathrm{RO}=2.81 \\
\text { UK: } \mathrm{RO}=2.82 \\
\text { After } \mathrm{SD} \text { measures } \\
\text { Austria: } \mathrm{Rt}=0.36 \\
\text { Belgium: } \mathrm{Rt}=0.51 \\
\text { Denmark: } \mathrm{Rt}=1.36 \\
\text { France: } \mathrm{Rt}=0.30 \\
\text { Germany: } \mathrm{Rt}=0.56 \\
\text { Italy: } \mathrm{Rt}=0.22 \\
\text { Norway: } \mathrm{Rt}=0.92 \\
\text { Spain: } \mathrm{Rt}=0.29 \\
\text { Sweden: } \mathrm{Rt}=2.01 \\
\text { Switzerland: } \mathrm{Rt}=0.53 \\
\text { UK: } \mathrm{Rt}=0.61\end{array}$ & \\
\hline $\begin{array}{l}\text { Voko et } \\
\text { al., } 2020 \\
\text { (45) }\end{array}$ & $\begin{array}{l}28 \text { European } \\
\text { countries }\end{array}$ & $\begin{array}{l}\text { Time } \\
\text { series }\end{array}$ & $\begin{array}{l}1 / 2- \\
18 / 4 / 20 \\
20\end{array}$ & $\begin{array}{l}\text { SD } \\
\text { measures } \\
\text { as applied } \\
\text { in each } \\
\text { country }\end{array}$ & N/A & $\begin{array}{l}\text { Before changepoint, the } \\
\text { incidence of new COVID- } 19 \\
\text { cases grew by } 24 \% \text { per day on } \\
\text { average. From the } \\
\text { changepoint, } \\
\text { this growth rate was reduced } \\
\text { to } 0.9 \%, 0.3 \% \text { increase, } \\
\text { and to } 0.7 \% \text { and } 1.7 \% \text { decrease } \\
\text { by increasing social } \\
\text { distancing quartiles. }\end{array}$ & \\
\hline $\begin{array}{l}\text { Coccia et } \\
\text { al., } 2021 \\
(46)\end{array}$ & $\begin{array}{l}\text { Austria, } \\
\text { France, } \\
\text { Italy, } \\
\text { Portugal, } \\
\text { Spain and } \\
\text { Sweden }\end{array}$ & $\begin{array}{l}\text { Observ } \\
\text { ational } \\
\text { (cohort } \\
\text { ) }\end{array}$ & $\begin{array}{l}15 / 04- \\
30 / 08 / 2 \\
020\end{array}$ & $\begin{array}{l}\text { 1) 15-day } \\
\text { lockdown } \\
\text { 2) } 61 \text {-day } \\
\text { lockdown }\end{array}$ & $\mathrm{N} / \mathrm{A}$ & Non-significant differences & $\begin{array}{l}\text { The average fatality rate of countries } \\
\text { with } 15 \text {-day lockdown was }-7.3 \\
\text { percent points lower than countries } \\
\text { with } 61 \text {-day lockdown }(p<0.005)\end{array}$ \\
\hline
\end{tabular}




\begin{tabular}{|c|c|c|c|c|c|c|c|}
\hline $\begin{array}{l}\text { Martinez- } \\
\text { Valero et } \\
\text { al., } 2020 \\
\text { (47) }\end{array}$ & $\begin{array}{l}\text { Belgium, } \\
\text { Denmark, } \\
\text { Finland, } \\
\text { France, } \\
\text { Austria, } \\
\text { Germany, } \\
\text { Iceland, } \\
\text { Ireland, } \\
\text { Italy, } \\
\text { Norway, } \\
\text { Holland, } \\
\text { Portugal, } \\
\text { Spain, } \\
\text { Sweden, } \\
\text { Switzerland } \\
\text { and the } \\
\text { United } \\
\text { Kingdom }\end{array}$ & $\begin{array}{l}\text { Observ } \\
\text { ational } \\
\text { (cohort } \\
\text { ) }\end{array}$ & $\begin{array}{l}\text { up to } \\
30 / 6 / 20 \\
20\end{array}$ & $\begin{array}{l}\mathrm{SD} \\
\text { measures }\end{array}$ & $\mathrm{N} / \mathrm{A}$ & $\begin{array}{l}\text { A high correlation coefficient } \\
\text { (R2 adjusted } 0.726 \text { ) was } \\
\text { documented in relation to the } \\
\text { time that elapsed until } \\
\text { lockdown together with the } \\
\text { number of tests performed }\end{array}$ & $\begin{array}{l}\text { The results showed that there is a } \\
\text { close correlation between the } \\
\text { number of deaths from COVID-19, } \\
\text { total and per million inhabitants, } \\
\text { concerning the days elapsed until } \\
\text { lockdown (R2 adjusted } 0.722 \text { and } \\
0.590 \text {, respectively) }\end{array}$ \\
\hline
\end{tabular}

\section{School closure}

\section{Modelling studies}

Among the 45 studies included in this current review, two examined in more depth the effectiveness of school closure as a separate measure. Rozhnova et al. (48) attempted to predict the impact of reducing school contacts in pandemic progression through an agent-structured transmission model with data from the Netherlands. The analysis showed that if complete school closure were implemented after the summer holidays in August 2020 , R would be reduced by $10 \%$, from 1.31 (95\% 1.15-2.07) to 1.18 (95\% 1.04-1.83). However, if school closure were enacted in November 2020, after implementing a partial lockdown since August, that would lead to a value of $\mathrm{R}$ of 1.00 (95\% 0.94-1.33), it could further decrease $\mathrm{R}$ by $16 \%$. Contact restrictions within the age group of 10-20 years old caused a slightly more significant reduction in Re compared to 5-10 years old. Notably, in the second wave of the pandemic, when primary and secondary schools remained open, their transmission role was limited. School closure was also assessed by Rypdal et al. (49) based on the population of two large cities of Norway, Oslo and Tromso, indicating that a controlled and gradual school re-opening would only have a slight increase in the reproduction number of less than 0.25 , and probably in the range between 0.10 and 0.14 , which would not substantially affect the infection rates. 
Table 13. Study characteristics and results for modelling studies on the effectiveness of school closure (n=2)

\begin{tabular}{|c|c|c|c|c|c|c|}
\hline \multirow{2}{*}{ Authors } & \multirow{2}{*}{$\begin{array}{c}\text { Country, Area/ } \\
\text { Population }\end{array}$} & \multirow{2}{*}{$\begin{array}{l}\text { Study } \\
\text { type }\end{array}$} & \multirow{2}{*}{ Time horizon } & \multirow{2}{*}{ Intervention(s) } & \multirow{2}{*}{ Comparator } & Results \\
\hline & & & & & & Cases \\
\hline $\begin{array}{l}\text { Rozhnova et } \\
\text { al., } 2021 \text { (48) }\end{array}$ & Netherlands & $\begin{array}{l}\text { Bayesian } \\
\text { model }\end{array}$ & $\begin{array}{l}27 / 02- \\
30 / 04 / 2020 \\
\text { (hospital } \\
\text { admission data) } \\
\text { April/May } 2020 \\
\text { (seroprevalence } \\
\text { data) }\end{array}$ & $\begin{array}{l}\text { School closure in } \\
\text { August and in } \\
\text { November }\end{array}$ & $\begin{array}{l}\text { Right before } \\
\text { school closure }\end{array}$ & 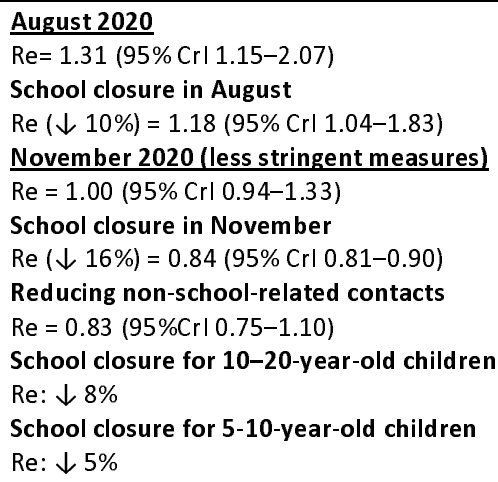 \\
\hline $\begin{array}{l}\text { Rypdal et al. } \\
2021 \text { (49) }\end{array}$ & $\begin{array}{l}\text { Norway (Oslo } \\
\text { and Tromso) }\end{array}$ & $\begin{array}{l}\text { IBM } \\
\text { model }\end{array}$ & $\begin{array}{l}\text { up to } \\
22 / 5 / 2020\end{array}$ & $\begin{array}{l}\text { Kindergarten re- } \\
\text { opening on } \\
20 / 4 / 2020 \text { and } \\
\text { school re-opening } \\
\text { on } 27 / 4 / 2020 \\
\text { since the closure } \\
\text { from } 13 / 3 / 2020\end{array}$ & $\begin{array}{l}\text { Before school } \\
\text { re-opening }\end{array}$ & $\begin{array}{l}\text { After school re-opening } \\
\text { Oslo: } \Delta R=0.10 \text { (SE } 0.004) \\
\text { Tromso: } \Delta R=0.14 \text { (SE 0.005) }\end{array}$ \\
\hline
\end{tabular}

\section{Case detection and management}

Four modelling studies assessed the effectiveness of case detection and management strategies in this systematic review. Willem et al. (50) used the Simulate Transmission of Infectious Diseases (STRIDE) model with data from Belgium in order to contribute to the evidence on the effectiveness of contact tracing strategies. They found that the crucial timeframe for the completion of contact tracing during this period of the epidemic was four days after symptoms' onset, while with a contact tracing strategy in place, an average decrease in hospital admissions of $22 \%$ in June and $57 \%$ in August could occur, assuming that at least $70 \%$ of the symptomatic cases are subjected to contact tracing and adhere to home isolation. Almagor et al. (51) developed an agent-based model based on the population of Glasgow, aiming at evaluating the effectiveness of a ContactTracing App (CTA). According to the results, the greatest reduction in overall and peak infections was noted when CTA was combined with a testing policy prioritising symptomatic cases. When 
medRxiv preprint doi: https://doi.org/10.1101/2021.11.11.21266216; this version posted November 11, 2021. The copyright holder for this preprint (which was not certified by peer review) is the author/funder, who has granted medRxiv a license to display the preprint in perpetuity.

It is made available under a CC-BY-NC-ND 4.0 International license .

CTA was adopted by $40-60 \%$ of the population and the testing capacity was between $1.5 \%$ and $3 \%$, overall cases would decrease by $18-23 \%$ of the population and peak cases by $70-85 \%$. In the case of $80 \%$ CTA adoption, the overall and peak cases would be reduced by an additional percentage of $7-12 \%$ and $4-19 \%$, respectively. In the scenario where only COVID-19 tests were performed without any tracing, if $3 \%$ of the population was tested weekly, the overall number of infections could only decrease from 44 to $31 \%$ (by $13 \%$ ), and the peak infections would reduce by $59 \%$. A testing capacity of $>3 \%$ did not lead to significant case reduction. The effectiveness of testing was also profound in the study of Gul et al. (40), who modelled different testing ratios in Germany. In more specific, testing ratios of $1 / 1000,5 / 1000,1 / 100$ and $5 / 100$ of the population were found to cause a reduction in the mean number of deaths by $1 \%, 10 \%, 15 \%, 60 \%$, respectively, compared to the no testing scenario. It could also be observed that random testing could be only considered effective if performed in over 5/1000 of the population. The authors noted that such testing numbers could be achieved regionally in smaller populations, but they may not be feasible for larger metropolitan cities. In the UK, Panovska-Griffiths et al. (52) also pointed out the significance of sufficient testing, tracing and isolating strategy to prevent a second COVID-19 wave during the autumn/winter of 2020. According to their model predictions, re-opening schools from September 1st, 2020, either full time or part-time with a rota system, along with the loosening of other SD measures, would induce a second pandemic wave in the absence of a scaled-up testing strategy. However, results showed that this might be prevented if a sufficient amount of symptomatic COVID-19 cases could be tested and an adequate number of their contacts could be traced. For example, in the case where $68 \%$ of contacts could be traced, approximately $65-75 \%$ of symptomatic cases would need to be tested and isolated, while if only $40 \%$ of contacts could be traced, the percentage of tested symptomatic cases would rise to $75-87 \%$. 
medRxiv preprint doi: https://doi.org/10.1101/2021.11.11.21266216; this version posted November 11, 2021. The copyright holder for this preprint (which was not certified by peer review) is the author/funder, who has granted medRxiv a license to display the preprint in perpetuity.

It is made available under a CC-BY-NC-ND 4.0 International license .

Table 14. Study characteristics and results for modelling studies on the effectiveness of case detection and management measures $(n=4)$

\begin{tabular}{|c|c|c|c|c|c|c|c|}
\hline \multirow{2}{*}{$\begin{array}{l}\text { Lead } \\
\text { Author, } \\
\text { Year }\end{array}$} & \multirow{2}{*}{$\begin{array}{c}\text { Country, } \\
\text { Area/ } \\
\text { Population }\end{array}$} & \multirow[b]{2}{*}{$\begin{array}{l}\text { Study } \\
\text { type }\end{array}$} & \multirow[b]{2}{*}{$\begin{array}{c}\text { Time } \\
\text { horizon }\end{array}$} & \multirow[b]{2}{*}{ Intervention(s) } & \multirow[b]{2}{*}{$\begin{array}{c}\text { Comparat } \\
\text { or }\end{array}$} & \multicolumn{2}{|l|}{ Results } \\
\hline & & & & & & Cases & Deaths/Hospital \\
\hline $\begin{array}{l}\text { Almagor } \\
\text { et al., } \\
2020 \\
(51)\end{array}$ & $\begin{array}{l}\text { Scotland, } \\
\text { Glasgow/ } \\
\text { Synthetic } \\
\text { populatio } \\
\text { n of circa } \\
103,000 \\
\text { agents } \\
\text { from } 2011 \\
\text { UK Census }\end{array}$ & $\begin{array}{l}\text { An } \\
\text { agent- } \\
\text { based } \\
\text { model }\end{array}$ & Undefined & $\begin{array}{l}\text { Contact-tracing } \\
\text { smartphone app } \\
\text { (CTA) + COVID-19 } \\
\text { detection tests }\end{array}$ & $\begin{array}{l}\text { No CTA } \\
\text { + testing }\end{array}$ & $\begin{array}{l}\text { Testing without CTA vs. no CTA + } \\
\text { testing } \\
\text { 3\% testing capacity: } \downarrow 13 \% \text { overall } \\
\text { infections, } \downarrow 59 \% \text { peak infections } \\
>3 \% \text { testing capacity: no further } \\
\text { decrease } \\
\text { CTA + testing prioritizing } \\
\text { symptomatic cases vs. no CTA + } \\
\text { testing } \\
40-60 \% \text { CTA adoption }+1.5-3 \% \\
\text { testing capacity: } \downarrow 18-23 \% \text { overall } \\
\text { infections, } \downarrow 70-85 \% \text { peak } \\
\text { infections } \\
80 \% \text { CTA adoption }+1.5-3 \% \\
\text { testing capacity: } \downarrow 30 \% \text { overall } \\
\text { infections, } \downarrow 89 \% \text { peak infections } \\
\text { CTA with no priority testing of } \\
\text { symptomatic cases vs. no CTA }+ \\
\text { testing } \\
40-80 \% \text { CTA adoption }+3 \% \text { testing } \\
\text { capacity: substantially more } \\
\text { infections than the scenario with } \\
\text { no CTA users }\end{array}$ & \\
\hline $\begin{array}{l}\text { Gul et } \\
\text { al., } 2020 \\
(40)\end{array}$ & Germany & $\begin{array}{l}\text { Monte } \\
\text { Carlo } \\
\text { model }\end{array}$ & $\begin{array}{l}\text { up to } \\
16 / 4 / 2020\end{array}$ & $\begin{array}{l}\text { 1) Testing ratio of } \\
\text { 1/1000 ppl } \\
\text { 2) Testing ratio of } \\
\text { 5/1000 ppl } \\
\text { 3) Testing ratio of } \\
\text { 1/100 ppl } \\
\text { 4) Testing ratio of } \\
\text { 5/100 ppl }\end{array}$ & $\begin{array}{l}\text { No } \\
\text { testing }\end{array}$ & & $\begin{array}{l}\frac{1 / 1000 \text { ppl vs no }}{\downarrow 1 \% \text { of deaths }} \\
\frac{5 / 1000 \text { ppl vs no }}{\downarrow 10 \% \text { of deaths }} \\
\frac{1 / 100 \text { ppl vs no }}{\downarrow 15 \% \text { of deaths }} \\
\frac{\mathbf{5} / \mathbf{1 0 0} \text { ppl vs no }}{\downarrow 60 \% \text { of deaths }}\end{array}$ \\
\hline $\begin{array}{l}\text { Panovsk } \\
\text { a- } \\
\text { Griffiths } \\
\text { et al., } \\
2020 \\
\text { (52) }\end{array}$ & UK & $\begin{array}{l}\text { Covasim } \\
\text { model }\end{array}$ & $\begin{array}{l}21 / 01- \\
17 / 06 / 202 \\
0\end{array}$ & $\begin{array}{l}\text { 1) } 68 \% \text { of contacts } \\
\text { traced/no scale-up } \\
\text { in testing } \\
\text { 2) } 68 \% \text { of contacts } \\
\text { are traced and } \\
\text { testing is scaled up } \\
\text { 3) } 40 \% \text { of contacts } \\
\text { are traced and } \\
\text { testing is scaledup }\end{array}$ & $\begin{array}{l}\text { No } \\
\text { testing }\end{array}$ & $\begin{array}{l}\text { Across both scenarios of school re- } \\
\text { opening the test-trace-isolate } \\
\text { strategy would need to test a } \\
\text { sufficiently large proportion of the } \\
\text { symptomatic cases and trace their } \\
\text { contacts with sufficiently large } \\
\text { coverage, for R to diminish below } \\
1\end{array}$ & \\
\hline $\begin{array}{l}\text { Willem } \\
\text { et al., } \\
2021 \\
(50)\end{array}$ & Belgium & $\begin{array}{l}\text { STRIDE } \\
\text { model }\end{array}$ & $\begin{array}{l}\text { Data up to } \\
30 / 4 / 2020 \\
\text { and } \\
\text { simulation } \\
\text { s up to } \\
31 / 8 / 2020\end{array}$ & $\begin{array}{l}\text { Contact tracing } \\
\text { strategy }\end{array}$ & $\begin{array}{l}\text { No } \\
\text { contact- } \\
\text { tracing }\end{array}$ & & $\begin{array}{l}\text { Average reduction in } \\
\text { hospital admissions } \\
\text { of } 22 \% \text { in June and } \\
57 \% \text { in August } \\
\text { assuming that } 70 \% \\
\text { of the symptomatic } \\
\text { cases are subjected } \\
\text { to contact tracing } \\
\text { and comply with } \\
\text { home isolation }\end{array}$ \\
\hline
\end{tabular}

\section{Hygiene measures}

Hygiene measures (i.e. facemasks) were only studied at the community level in this review, and

hence one modelling study, one RCT and one quasi-experimental study were considered eligible. 
medRxiv preprint doi: https://doi.org/10.1101/2021.11.11.21266216; this version posted November 11, 2021. The copyright holder for this preprint (which was not certified by peer review) is the author/funder, who has granted medRxiv a license to display the preprint in perpetuity.

It is made available under a CC-BY-NC-ND 4.0 International license .

\section{Modelling studies}

Heald et al. (53) developed a sequential assessment of the risk reduction provided by face coverings in public transport and retail shops in the UK using a step-by-step approach. They calculated the infection risk ratio and found a reduction of the risk score from 58.9 to 58.0 for a face covering efficacy of $20 \%$, to 57.2 for a $40 \%$ efficacy, to 56.3 for an efficacy of $60 \%$, and to 55.5 for an efficacy of $80 \%$. A surgical mask, with an efficacy of over $90 \%$, as used in hospitals, would reduce overall risk by $6.6 \%$ up to the maximum of $7.3 \%$. The findings also showed that, with an $\mathrm{R}$ value of 0.8 and face-covering of $40 \%$ effectiveness, average infections would be reduced by $844 /$ week, hospital admissions by $8 /$ week and deaths by $0.6 /$ week. Nevertheless, If $\mathrm{R}$ was 1.0 , the average community infections would remain at $29,400 /$ week, and face coverings would reduce average weekly infections by 3,930 , deaths by 2.9 /week and hospital admissions by $36 /$ week. Overall, the study showed that face-coverings, even with appropriate materials and maximum compliance on handling and wearing, produce limited benefits when used at low reinfection rates. Also, early implementation of such measured has a significant role in their effectiveness.

\section{$\underline{\text { Non-Modelling studies }}$}

An RCT was performed by Bundgaard et al. (54) to evaluate the effectiveness of voluntary surgical face mask use in a sample of 4862 adults with no prior or current COVID-19 diagnosis or relevant symptoms who spent more than three hours out of home and have contact with other individuals. The results showed that 42 and 53 COVID-19 cases occurred in the intervention and control groups, respectively, without a statistically significant difference between them. As concluded, the recommendation of surgical mask use, supportively to other NPIs, did not decrease the infection rate by more than $50 \%$ among wearers in the context of a community with sufficient SD measures, modest infection rates, and uncommon general mask use. 
medRxiv preprint doi: https://doi.org/10.1101/2021.11.11.21266216; this version posted November 11, 2021. The copyright holder for this preprint (which was not certified by peer review) is the author/funder, who has granted medRxiv a license to display the preprint in perpetuity. It is made available under a CC-BY-NC-ND 4.0 International license .

The mandatory use of face masks was studied by Mitze et al. (55) in Germany, both in Jena and other regions. In Jena, the use of face masks in public transport and shops became mandatory before its compulsory implementation in all federal states, and within a 20-day period, it managed to reduce the number of newly registered cases by $75 \%$ relative compared to the control populations. Regarding the daily growth rate, it was reduced by approximately $70 \%$, and however, when the analysis was performed in other regions, the effect was not as sizeable in the daily growth rate as it amounted to $14 \%$, which rose, however, to $47 \%$ when only large cities were taken into consideration. The authors concluded that the timing of measures implementation may have played a crucial role in its effectiveness. 
medRxiv preprint doi: https://doi.org/10.1101/2021.11.11.21266216; this version posted November 11, 2021. The copyright holder for this preprint (which was not certified by peer review) is the author/funder, who has granted medRxiv a license to display the preprint in perpetuity.

It is made available under a CC-BY-NC-ND 4.0 International license .

Table 15. Study characteristics and results for modelling and non-modelling studies on the effectiveness of case detection and management measures $(n=3)$

\begin{tabular}{|c|c|c|c|c|c|c|}
\hline \multirow{2}{*}{ Lead Author, Year } & \multirow{2}{*}{$\begin{array}{c}\text { Country, } \\
\text { Area/ } \\
\text { Population }\end{array}$} & \multirow{2}{*}{ Study type } & \multirow{2}{*}{ Time horizon } & \multirow{2}{*}{ Intervention(s) } & \multirow{2}{*}{ Comparator } & Results \\
\hline & & & & & & Cases \\
\hline $\begin{array}{l}\text { Heald et al., } \\
2021 \text { (53) }\end{array}$ & UK & $\begin{array}{l}\text { Modelling } \\
\text { study } \\
\text { (undefined } \\
\text { model) }\end{array}$ & $\begin{array}{l}\text { up to July } \\
2020\end{array}$ & $\begin{array}{l}\text { Mandatory mass } \\
\text { use of face } \\
\text { coverings on } \\
\text { public transport } \\
\text { from } 15 / 6 / 2020, \\
\text { and in retail } \\
\text { outlets from } \\
24 / 7 / 2020\end{array}$ & No face mask & $\begin{array}{l}\text { Face mask 20\%: Infection Risk } \\
\text { Score }=58(\downarrow 1.5 \%) \\
\text { Face mask } \mathbf{4 0 \%} \text { : Infection Risk } \\
\text { Score }=57.2(\downarrow 2.9 \%) \\
\text { Face mask } 60 \%: \text { Infection Risk } \\
\text { Score }=56.3(\downarrow 4.4 \%) \\
\text { Face mask } 80 \%: \text { Infection Risk } \\
\text { Score= } 55.5(\downarrow 5.8 \%)\end{array}$ \\
\hline $\begin{array}{l}\text { Bundgaard et } \\
\text { al., } 2020 \text { (54) }\end{array}$ & $\begin{array}{l}\text { Denmark/ } \\
4,862 \text { adults } \\
\text { without } \\
\text { COVID-19 } \\
\text { who spend } \\
>3 \text { hours per } \\
\text { day outside } \\
\text { home with } \\
\text { exposure to } \\
\text { other people }\end{array}$ & $\begin{array}{l}\text { Experimental } \\
\text { study (Two- } \\
\text { arm, } \\
\text { unblinded, } \\
\text { randomised } \\
\text { controlled } \\
\text { trial) }\end{array}$ & $\begin{array}{l}\text { April-May } \\
2020\end{array}$ & $\begin{array}{l}\text { SD measures + } \\
\text { face mask } \\
\text { (surgical) } \\
\text { recommendation } \\
\text { outside home }\end{array}$ & $\begin{array}{l}\text { SD measures + } \\
\text { no face mask } \\
\text { (surgical) } \\
\text { recommendation }\end{array}$ & $\begin{array}{l}\text { Intervention group } \\
42 \text { participants } \\
\text { Control group } \\
53 \text { control participants } \\
\text { Between-group difference }=- \\
0.3 \text { percentage point }(95 \% \mathrm{Cl} \text {, } \\
-1.2 \text { to } 0.4 \text { percentage } \\
\text { point; } \mathrm{P}=0.38) \\
O R=0.82[\mathrm{Cl}, 0.54 \text { to } 1.23] \\
\mathrm{P}=0.33) \text {; }\end{array}$ \\
\hline $\begin{array}{l}\text { Mitze et al., } \\
2020 \text { (55) }\end{array}$ & $\begin{array}{l}\text { Germany, } \\
\text { Jena }\end{array}$ & $\begin{array}{l}\text { Quasi- } \\
\text { experimental } \\
\text { study }\end{array}$ & $\begin{array}{l}\text { April } 2020 \\
\text { (20-days } \\
\text { intervention } \\
\text { period) }\end{array}$ & $\begin{array}{l}\text { Mandatory mass } \\
\text { use of face masks } \\
\text { in public } \\
\text { transport and } \\
\text { shops from } \\
6 / 4 / 2020\end{array}$ & Before mask use & $\begin{array}{l}\text { 20-day mandatory mask use } \\
\text { in public transport and shops } \\
\text { vs. control } \\
\text { Jena } \\
\downarrow 23 \% \text { in cumulative cases } \\
\downarrow 75 \% \text { in newly registered } \\
\text { cases } \\
\downarrow 70 \% \text { in daily growth rate } \\
\text { Other regions } \\
\downarrow 8.9 \% \text { in cumulative cases } \\
\downarrow 51.2 \% \text { in newly registered } \\
\text { cases } \\
\downarrow 14 \% \text { percentage points in } \\
\text { daily growth rate }\end{array}$ \\
\hline
\end{tabular}

\section{DISCUSSION}

This systematic review aimed to update the evidence on the effectiveness of NPIs implemented at the meso and macro level to curb the COVID-19 pandemic in the European Region. Given the pandemic's sudden escalation, the rapidly rising numbers of cases and deaths and the exhaustion of healthcare systems, policymakers had to make timely decisions on the type of strategies to be adopted with only limited evidence-informed guidance, especially in the early pre-vaccine stages of the pandemic which are primarily reflected within this review. The literature presented here predominantly reports on research undertaken during 2020, thus offering a comprehensive 
medRxiv preprint doi: https://doi.org/10.1101/2021.11.11.21266216; this version posted November 11, 2021. The copyright holder for this preprint (which was not certified by peer review) is the author/funder, who has granted medRxiv a license to display the preprint in perpetuity.

It is made available under a CC-BY-NC-ND 4.0 International license .

assessment of the effectiveness of NPIs in Europe during the first and second waves of the COVID19 pandemic, in spring and autumn 2020, respectively.

\section{Physical distancing measures}

Physical distancing measures, including the closure of educational institutions, entertainment venues, non-essential businesses, gyms and sports, workplace closure, bans on gatherings, cancellation of events, isolation of cases and quarantine of contacts, and stay-at-home recommendations/orders were a core component of the control strategies for the containment of COVID-19 pandemic in most of the studied countries. In this current systematic review, most studies attempted to investigate various combinations of physical distancing measures, with lockdown strategies gaining the most attention. Overall, both empirical data and modelling studies showed that physical distancing measures slowed COVID-19 spread and reduced hospital/ICU admissions and mortality in all EU/UK/EEA countries included in this review. The individual effect of individual NPIs is difficult to be estimated due to their parallel implementation and the multifactorial nature that affects their impact, both within and across countries.

A significant overarching factor that was noted to impact physical distancing measures' effectiveness is the timing of the implementation, a factor noted by both modelling and observational studies. Palladino et al. (12) predicted that a 7-day earlier lockdown introduction would have averted a significant number of cases, deaths, hospital and ICU admissions in Italy. Moreover, it was modelled that the daily number of cases would have been reduced by $78-92 \%$ in France, Italy, Spain and the UK, respectively, if in each country the lockdown would have started three days after the first 50 cases, and not the actual days of enactment (43). Consistent were the results of Casares \& Khan (19), who showed with a SIR model that the timing of implementation plays a significant role in COVID-19 spread. The positive impact of an earlier performance of lockdown measures was also profound in the non-modelling studies performed in Italy that 
indicated that regions with a delayed lockdown implementation had a peak with a higher number of cases than those with a shorter implementation delay. (16) (16)

In addition to timing, the duration of implementation is also a significant aspect that has to be taken into consideration in the decision-making process. In general, the results of the studies included in this systematic review used simulation models that differ in design, baseline parameters and assumptions; however, they indicated that an earlier lifting of SD measures would lead to an increase in cases in Germany (31) and higher hospitalisation rates in Italy (13). Goscé et al. (23) concluded that an extended lockdown for two-three more months would be the most effective, although other measures including shielding of older people, mass testing and facemask use could all synergistically lead to a reduction of cases and deaths. A recent systematic review, published in April 2020, noted that findings consistently indicate that quarantine measures are important in reducing incidence and mortality during the COVID-19 pandemic, although there is uncertainty over the magnitude of the effect (56). Although lockdowns have an impact on SARSCoV-2 transmission, the duration itself depends on many factors, such as the COVID-19 spread at the time of control initiation, the population's level of compliance, and the capacity of the healthcare system. At the same time, as they also have an impact on population wellbeing $(57,58)$ and the economy (46), a fine balance is needed between mitigating the pandemic and promoting economic and social wellbeing.

Another critical factor noted by multiple authors to highly affect the effectiveness of NPIs is the level of acceptance, perceived effectiveness, and compliance from the public, which, however, were not the focus of this specific review. Only one study within our review (36) focused on the level of population compliance with simulations showing that the benefit in pandemic mitigation increases with the increase of population adherence to the control measures. Data collected on March 2020, across the G7 countries showed that those who were concerned about the impact of 
medRxiv preprint doi: https://doi.org/10.1101/2021.11.11.21266216; this version posted November 11, 2021. The copyright holder for this preprint (which was not certified by peer review) is the author/funder, who has granted medRxiv a license to display the preprint in perpetuity.

It is made available under a CC-BY-NC-ND 4.0 International license .

COVID-19 on their own or their children's education or on their personal income were more likely to practice personal protective measures and physical distancing (59).

As for school closure, the two included modelling studies indicated only a moderate effect on COVID-19 cases when implemented individually. At the same time, if appropriate measures were applied systematically in school premises, R would not be significantly affected. Similar conclusions were presented in the rapid systematic review of Viner et al., who underlined that the only study examining school closures independently found relatively marginal impact by preventing only 2$4 \%$ of deaths, compared to other physical distancing interventions (60). Considering transmission, in the review conducted by Suk et al. children were most frequently transmitting SARS-CoV-2 in household settings, while examples of children as index cases in school settings were rare (61).

\section{Case detection and management and hygiene measures}

The evidence on the effectiveness of case detection and management strategies is limited due to the lack of empirical data within this review, as only four modelling studies on this topic were included. Overall, the significant contribution of the timely isolation of a high proportion of cases for an adequate duration in limiting the SARS-CoV-2 spread, combined with contact tracing and quarantine of contacts, was highlighted in all studies. However, given the modelling design, the actual effect of the case detection and management measures as implemented in each country has not been captured along with the contributing factors, among which the availability of tests has a crucial role.

With regards to hygiene measures, only three studies were included in this review evaluating the effectiveness of face masks with different methodological designs in Europe at the meso and macro level (53-55). In general, the results indicated that they have a supportive effect in mitigating the pandemic spread. However, these data reflect on the early period of the pandemic when people were not as familiar with personal protective measures as on the later stages. 
medRxiv preprint doi: https://doi.org/10.1101/2021.11.11.21266216; this version posted November 11, 2021. The copyright holder for this preprint (which was not certified by peer review) is the author/funder, who has granted medRxiv a license to display the preprint in perpetuity.

It is made available under a CC-BY-NC-ND 4.0 International license .

Despite the lack of studies that have assessed the impact of facemasks at the community and population level, there is a plethora of evidence that indicate the role of facemasks to mitigate respiratory pandemics, both as a cost effective preventive measure (3) and as a mitigation measure for COVID-19 transmission $(62,63)$.

Given that the studies included in this current review are heterogeneous regarding models, setting, timeframe and NPI interventions assessed, a direct comparison of the same class of NPIs in different countries should be performed with extreme caution. Discrepancies were noted in different countries even in the implementation of high visibility measures, like the stay-at-home orders. Additionally, the same national measures were implemented in a very different way at different times within the same country, with stay-at-home orders in spring 2020 being much stricter than in the autumn of the same year. One study that attempted to rank the effectiveness of COVID-19 interventions worldwide noted that the performance of all NPIs depends highly on the geographical region and the socioeconomic context, while accountability to government and political stability were found to exert influence(64). A more recent review of only empirical studies worldwide conducted by Mendez-Brito et al. (65) indicated that school closure, followed by workplace and entertainment venue closure, as well as bans of public events were the most effective NPIs, concluding that an early response and a combination of specific physical distancing measures are of crucial importance for the reduction of COVID-19 cases and deaths.

This report is part of the ECDC work related to collecting and analysing information on NPIs implemented for the COVID-19 pandemic. Within this frame, information on NPIs implemented in the EU/EEA since $1^{\text {st }}$ January 2020 is gathered in the ECDC-JRC Response Measures Database, which is publicly available at https://covid-statistics.jrc.ec.europa.eu/RMeasures. 
medRxiv preprint doi: https://doi.org/10.1101/2021.11.11.21266216; this version posted November 11, 2021. The copyright holder for this preprint (which was not certified by peer review) is the author/funder, who has granted medRxiv a license to display the preprint in perpetuity.

It is made available under a CC-BY-NC-ND 4.0 International license .

\section{Strengths and limitations}

Our systematic review has several strengths, including the systematic approach during study identification, data extraction and quality appraisal that was applied. Some limitations should also be acknowledged. We assessed peer-reviewed and published evidence available until April 2021, much of which included the period before December 2020, and hence the information provided does not adequately cover NPIs in place during the circulation of all variants of concern. As per our inclusion criteria, only studies based in EU/EEA and UK were assessed, and accordingly, the results may not reflect the effectiveness of NPI implementation in other contexts globally - although other systematic reviews of a broader scope indicate similar findings $(66,67)$. Furthermore, a significant percentage of identified studies were based on mathematical modelling studies that require many assumptions related to the model design, which may lead to variability in model predictions and uncertainty for decision-makers. There was, furthermore, significant heterogeneity in study designs and studied interventions/combination of interventions, which only allowed for a narrative presentation of the results. Also, given that NPI effectiveness depends on the implementation, the personal protective measures that are probably implemented in parallel, demographic characteristics, and compliance levels, direct comparisons across countries and across NPIs were not possible.

\section{Conclusions}

It will continue to be important to refine understandings of the effectiveness of NPIs for controlling COVID-19, and the evidence generated during the COVID-19 pandemic may also be applicable to future pandemics. The findings of this review provide a narrative synthesis of the literature available for the European Region and could also be the basis for the development of a future guiding framework, including best practices and approaches to policymakers primarily in the EU and EEA countries. In conclusion, NPIs, as assessed within the context of this systematic 
medRxiv preprint doi: https://doi.org/10.1101/2021.11.11.21266216; this version posted November 11, 2021. The copyright holder for this preprint (which was not certified by peer review) is the author/funder, who has granted medRxiv a license to display the preprint in perpetuity. It is made available under a CC-BY-NC-ND 4.0 International license .

review at the macro and meso level, are effective in reducing transmission rates, hospitalisation rates and deaths in the European Region and may be applied as response strategies to reduce the burden of COVID-19 in forthcoming waves as well as in other respiratory viruses and future outbreaks. However, particular attention should be paid on the timing and duration of these measures in order maximum benefits to be achieved. 


\section{ACKNOWLEDGEMENTS}

We would like to thank Chrysa Chatzopoulou and Katerina Papathanasaki for contributing to data archiving and management. We would also like to thank Rene Niehus for his helpful comments on an earlier version of this work.

This report was commissioned by the European Centre for Disease Prevention and Control (ECDC), to the PREP-EU Consortium, coordinated by the School of Medicine, University of Crete, under specific contract No.7 ECD. 23661 within Framework contract ECDC/2019/001 Lot 1B.

Disclaimer: This report was produced under a service contract with the European Centre for Disease Prevention and Control (ECDC), acting under the mandate from the European Commission. The information and views set out in this piece of work are those of the authors and do not necessarily reflect the official opinion of the Commission/Agency. The Commission/Agency do not guarantee the accuracy of the data included in this analysis. Neither the Commission/Agency nor any person acting on the Commission's/Agency's behalf may be held responsible for the use which may be made of the information contained therein.

\section{DATA AVAILABILITY STATEMENT}

Data sharing not applicable as no datasets generated and/or analysed for this study.

\section{CONFLICTS OF INTEREST/COMPETING INTERESTS}

None to report.

\section{ETHICS STATEMENT}

For the purposes of this review publicly accessible documents were used as evidence, and, hence, no ethics approval was required. 


\section{References}

1. COVID-19 situation update worldwide, as of week 35, updated 9 September 2021. 2021

2. Risk Assessment: Risk related to spread of new SARS-CoV-2 variants of concern in the EU/EEA.

2021.

3. Vardavas C, Nikitara K, Zisis K, Athanasakis K, Phalkey R, Leonardi-Bee J, et al. Cost-effectiveness of emergency preparedness measures in response to infectious respiratory disease outbreaks: a systematic review and econometric analysis. BMJ Open. 2021;11(4):e045113.

4. ECDC. Assessing SARS-CoV-2 circulation, variants of concern, non-pharmaceutical interventions and vaccine rollout in the EU/EEA, 16th update. Stockholm; 2021.

5. Walker PGT, Whittaker C, Watson OJ, Baguelin M, Winskill P, Hamlet A, et al. The impact of COVID19 and strategies for mitigation and suppression in low- and middle-income countries. Science.

2020;369(6502):413-22.

6. Flaxman S, Mishra S, Gandy A, Unwin HJT, Mellan TA, Coupland H, et al. Estimating the effects of non-pharmaceutical interventions on COVID-19 in Europe. Nature. 2020;584(7820):257-61.

7. Schardt C, Adams MB, Owens T, Keitz S, Fontelo P. Utilization of the PICO framework to improve searching PubMed for clinical questions. BMC Med Inform Decis Mak. 2007;7:16.

8. Tufanaru C, Munn Z, Aromataris E, Campbell J, Hopp L. Chapter 3: Systematic reviews of effectiveness. In: Aromataris E, Munn Z (Editors). JBI Manual for Evidence Synthesis. JBI. 2020.

9. Care cIEPaOo. Suggested risk of bias criteria for EPOC reviews 1 . Risk of bias for studies with a separate control group. 2017:1-4.

10. Burns J, Movsisyan A, Stratil JM, Biallas RL, Coenen M, Emmert-Fees KMF, et al. International travel-related control measures to contain the COVID-19 pandemic: a rapid review. Cochrane Database of Systematic Reviews. 2021.

11. Gatto M, Bertuzzo E, Mari L, Miccoli S, Carraro L, Casagrandi R, et al. Spread and dynamics of the COVID-19 epidemic in Italy: Effects of emergency containment measures. Proceedings of the National Academy of Sciences of the United States of America. 2020;117:10484-91.

12. Palladino R, Bollon J, Ragazzoni L, Barone-Adesi F. Excess deaths and hospital admissions for COVID19 due to a late implementation of the lockdown in Italy. International Journal of Environmental Research and Public Health. 2020;17:1-6.

13. Marzianoa V, Guzzettaa G, Rondinone BM, Boccuni F, Riccardo F, Bella A, et al. Retrospective analysis of the Italian exit strategy from COVID-19 lockdown. Proceedings of the National Academy of Sciences of the United States of America. 2021;118.

14. Sjödin H, Wilder-Smith A, Osman S, Farooq Z, Rocklöv J. Only strict quarantine measures can curb the coronavirus disease (COVID-19) outbreak in Italy, 2020. Eurosurveillance. 2020;25(13):2000280.

15. Silverio A, Di Maio M, Ciccarelli M, Carrizzo A, Vecchione C, Galasso G. Timing of national lockdown and mortality in COVID-19: The Italian experience. International Journal of Infectious Diseases. 2020;100:193-5.

16. Timelli L, Girardi E. Effect of timing of implementation of containment measures on Covid-19 epidemic. The case of the first wave in Italy. PLOS ONE. 2021;16:1-10.

17. Lilleri D, Zavaglio F, Gabanti E, Gerna G, Arbustini E. Analysis of the SARS-CoV-2 epidemic in Italy: The role of local and interventional factors in the control of the epidemic. PLOS ONE. 2020;15:1-12.

18. Hyafil A, Moriña D. Analysis of the impact of lockdown on the reproduction number of the SARSCov-2 in Spain. Gaceta Sanitaria. 2021;35:453-8.

19. Casares $\mathrm{M}$, Khan $\mathrm{H}$. The timing and intensity of social distancing to flatten the COVID-19 curve: The case of Spain. International Journal of Environmental Research and Public Health. 2020;17:1-14.

20. Santamaría L, Hortal J. Since January 2020 Elsevier has created a COVID-19 resource centre with free information in English and Mandarin on the novel coronavirus COVID- 19. The COVID-19 resource centre is hosted on Elsevier Connect, the company ' s public news and information 2020.

21. Liu Y, Tang JW, Lam TTY. Transmission dynamics of the COVID-19 epidemic in England. International Journal of Infectious Diseases. 2021;104:132-8.

22. Rice K, Wynne B, Martin V, Ackland GJ. Effect of school closures on mortality from coronavirus disease 2019: old and new predictions. BMJ. 2020:m3588. 
23. Goscé L, Phillips PA, Spinola P, Gupta DRK, Abubakar PI. Modelling SARS-COV2 Spread in London: Approaches to Lift the Lockdown. J Infect. 2020;81(2):260-5.

24. Davies NG, Barnard RC, Jarvis Cl, Russell TW, Semple MG, Jit M, et al. Association of tiered restrictions and a second lockdown with COVID-19 deaths and hospital admissions in England: a modelling study. The Lancet Infectious Diseases. 2021;21:482-92.

25. Yang P, Yang G, Qi J, Sheng B, Yang Y, Zhang S, et al. The effect of multiple interventions to balance healthcare demand for controlling COVID-19 outbreaks: a modelling study. Scientific Reports. 2021;11:1-13.

26. Mensah AA, Sinnathamby M, Zaidi A, Coughlan L, Simmons R, Ismail SA, et al. Since January 2020 Elsevier has created a COVID-19 resource centre with free information in English and Mandarin on the novel coronavirus COVID-19. The COVID-19 resource centre is hosted on Elsevier Connect, the company ' s public news and information 2020.

27. Bernal JL, Sinnathamby MA, Elgohari S, Zhao H, Obi C, Coughlan L, et al. The impact of social and physical distancing measures on COVID-19 activity in England: Findings from a multi-tiered surveillance system. Eurosurveillance. 2021;26:1-11.

28. Di Domenico L, Pullano G, Sabbatini CE, Boëlle PY, Colizza V. Impact of lockdown on COVID-19 epidemic in île-de-France and possible exit strategies. BMC Medicine. 2020;18:1-13.

29. Roche B, Garchitorena A, Roiz D. The impact of lockdown strategies targeting age groups on the burden of COVID-19 in France. Epidemics. 2020;33:100424.

30. Spaccaferri G, Larrieu S, Pouey J, Calba C, Benet T, Sommen C, et al. Early assessment of the impact of mitigation measures to control COVID-19 in 22 French metropolitan areas, October to November 2020. Eurosurveillance. 2020;25:1-5.

31. Aravindakshan A, Boehnke J, Gholami E, Nayak A. Preparing for a future COVID-19 wave: insights and limitations from a data-driven evaluation of non-pharmaceutical interventions in Germany. Scientific Reports. 2020;10:1-14.

32. Schlosser F, Maier BF, Jack O, Hinrichs D, Zachariae A, Brockmann D. COVID-19 lockdown induces disease-mitigating structural changes in mobility networks. Proceedings of the National Academy of Sciences of the United States of America. 2020;117:32883-90.

33. Wieland T. A phenomenological approach to assessing the effectiveness of COVID-19 related nonpharmaceutical interventions in Germany. Safety Science. 2020;131:104924.

34. Sypsa V, Roussos S, Paraskevis D, Lytras T, Tsiodras S, Hatzakis A. Effects of social distancing measures during the first epidemic wave of severe acute respiratory syndrome infection, Greece. Emerging Infectious Diseases. 2021;27:452-62.

35. Ricoca Peixoto[ V, Vieira A, Aguiar P, Carvalho C, Thomas DR, Abrantes A. Initial Assessment of the Impact of the Emergency State Lockdown Measures on the 1 st Wave of the COVID-19 Epidemic in Portugal Avaliação Inicial do Impacto das Medidas de Confinamento do Estado de Emergência na Primeira Onda da Epidemia de COVID-19 em Po. Acta Médica Portuguesa. 2020;33:733-41.

36. Pais RJ, Taveira N. Predicting the evolution and control of the COVID-19 pandemic in Portugal. F1000Research. 2020;9:283.

37. Sjödin H, Johansson AF, Brännström Å, Farooq Z, Kriit HK, Wilder-Smith A, et al. COVID-19 healthcare demand and mortality in Sweden in response to non-pharmaceutical mitigation and suppression scenarios. International Journal of Epidemiology. 2020;49:1443-53.

38. Valentin JB, Møller $\mathrm{H}$, Johnsen SP. The basic reproduction number can be accurately estimated within 14 days after societal lockdown: The early stage of the COVID-19 epidemic in Denmark. PLoS One. 2021;16(2):e0247021.

39. Ingelbeen B, Peckeu L, Laga M, Hendrix I, Neven I, van der Sande MAB, et al. Reducing contacts to stop SARS-CoV-2 transmission during the second pandemic wave in Brussels, Belgium, August to November 2020. Eurosurveillance. 2021;26:3-9.

40. Gul S, Tuncay K, Binici B, Aydin BB. Transmission dynamics of Covid-19 in Italy, Germany and Turkey considering social distancing, testing and quarantine. Journal of Infection in Developing Countries. 2020;14:713-20.

41. Bryant $P$, Elofsson A. Estimating the impact of mobility patterns on COVID-19 infection rates in 11 European countries. PeerJ. 2020;8:1-17. 
42. Belloir A, Blanquart F. Since January 2020 Elsevier has created a COVID-19 resource centre with free information in English and Mandarin on the novel coronavirus COVID- 19. The COVID-19 resource centre is hosted on Elsevier Connect, the company 's public news and information 2020.

43. Palladino R, Bollon J, Ragazzoni L, Barone-Adesi F. Effect of timing of implementation of the lockdown on the number of deaths for COVID-19 in four European countries. Disaster Medicine and Public Health Preparedness. 2020:2020-2.

44. Khataee H, Scheuring I, Czirok A, Neufeld Z. Effects of social distancing on the spreading of COVID19 inferred from mobile phone data. Scientific Reports. 2021;11:1-9.

45. Vokó Z, Pitter JG. The effect of social distance measures on COVID-19 epidemics in Europe: an interrupted time series analysis. Geroscience. 2020;42:1075-82.

46. Coccia M. The relation between length of lockdown, numbers of infected people and deaths of Covid-19, and economic growth of countries: Lessons learned to cope with future pandemics similar to Covid-19 and to constrain the deterioration of economic system. Science of The Total Environment. 2021;775:145801.

47. Martínez-Valeroa C, Miranda JD, Martín-Sáncheza FJ. The impact of time to impose lockdown on COVID-19 cases and deaths in European countries. Med Clin (Barc). 2020;73:2-3.

48. Rozhnova G, van Dorp CH, Bruijning-Verhagen P, Bootsma MCJ, van de Wijgert JHHM, Bonten MJM, et al. Model-based evaluation of school- and non-school-related measures to control the COVID-19 pandemic. Nature Communications. 2021;12:1-11.

49. Rypdal M, Rypdal V, Jakobsen PK, Ytterstad E, Løvsletten O, Klingenberg C, et al. Modelling suggests limited change in the reproduction number from reopening norwegian kindergartens and schools during the COVID-19 pandemic. PLOS ONE. 2021;16:1-13.

50. Willem L, Abrams S, Libin PJK, Coletti P, Kuylen E, Petrof O, et al. The impact of contact tracing and household bubbles on deconfinement strategies for COVID-19. Nature Communications. 2021;12:1-9.

51. Almagor J, Picascia S. Exploring the effectiveness of a COVID-19 contact tracing app using an agentbased model. Scientific Reports. 2020;10:1-11.

52. Panovska-Griffiths J, Kerr CC, Stuart RM, Mistry D, Klein DJ, Viner RM, et al. Determining the optimal strategy for reopening schools, the impact of test and trace interventions, and the risk of occurrence of a second COVID-19 epidemic wave in the UK: a modelling study. The Lancet Child and Adolescent Health. 2020;4:817-27.

53. Heald AH, Stedman M, Tian Z, Wu P, Fryer AA. Modelling the impact of the mandatory use of face coverings on public transport and in retail outlets in the UK on COVID-19-related infections, hospital admissions and mortality. International Journal of Clinical Practice. 2021;75.

54. Bundgaard H, Bundgaard JS, Raaschou-Pedersen DET, von Buchwald C, Todsen T, Norsk JB, et al. Effectiveness of Adding a Mask Recommendation to Other Public Health Measures to Prevent SARS-CoV-2 Infection in Danish Mask Wearers : A Randomized Controlled Trial. Annals of internal medicine.

2021;174:335-43.

55. Mitze T, Kosfeld R, Rode J, Walde K. Face masks considerably reduce COVID-19 cases in Germany. Proceedings of the National Academy of Sciences of the United States of America. 2020;117:32293-301.

56. Nussbaumer-Streit B, Mayr V, Dobrescu Al, Chapman A, Persad E, Klerings I, et al. Quarantine alone or in combination with other public health measures to control COVID-19: a rapid review. Cochrane Database Syst Rev. 2020;9(9):Cd013574.

57. Brooks SK, Webster RK, Smith LE, Woodland L, Wessely S, Greenberg N, et al. The psychological impact of quarantine and how to reduce it: rapid review of the evidence. Lancet. 2020;395(10227):912-20.

58. Niedzwiedz CL, Green MJ, Benzeval M, Campbell D, Craig P, Demou E, et al. Mental health and health behaviours before and during the initial phase of the COVID-19 lockdown: longitudinal analyses of the UK Household Longitudinal Study. J Epidemiol Community Health. 2021;75(3):224-31.

59. Vardavas $\mathrm{Cl}$, Odani S, Nikitara K, El Banhawi $\mathrm{H}$, Kyriakos $\mathrm{CN}$, Taylor L, et al. Perceptions and practice of personal protective behaviors to prevent COVID-19 transmission in the G7 nations. Population Medicine. 2020;2(June).

60. Viner RM, Russell SJ, Croker H, Packer J, Ward J, Stansfield C, et al. School closure and management practices during coronavirus outbreaks including COVID-19: a rapid systematic review. Lancet Child Adolesc Health. 2020;4(5):397-404. 
61. Suk JE, Vardavas C, Nikitara K, Phalkey R, Leonardi-Bee J, Pharris A, et al. The role of children in the transmission chain of SARS-CoV-2: a systematic review and update of current evidence. medRxiv. 2020:2020.11.06.20227264.

62. Li Y, Liang M, Gao L, Ayaz Ahmed M, Uy JP, Cheng C, et al. Face masks to prevent transmission of COVID-19: A systematic review and meta-analysis. Am J Infect Control. 2021;49(7):900-6.

63. Chu DK, AkI EA, Duda S, Solo K, Yaacoub S, Schünemann HJ. Physical distancing, face masks, and eye protection to prevent person-to-person transmission of SARS-CoV-2 and COVID-19: a systematic review and meta-analysis. Lancet. 2020;395(10242):1973-87.

64. Haug N, Geyrhofer L, Londei A, Dervic E, Desvars-Larrive A, Loreto V, et al. Ranking the effectiveness of worldwide COVID-19 government interventions. Nat Hum Behav. 2020;4(12):1303-12.

65. Mendez-Brito A, El Bcheraoui C, Pozo-Martin F. Systematic review of empirical studies comparing the effectiveness of non-pharmaceutical interventions against COVID-19. Journal of Infection. 2021;83:28193.

66. Liu Y, Morgenstern C, Kelly J, Lowe R, Jit M. The impact of non-pharmaceutical interventions on SARS-CoV-2 transmission across 130 countries and territories. BMC Med. 2021;19(1):40.

67. Li Y, Campbell H, Kulkarni D, Harpur A, Nundy M, Wang X, et al. The temporal association of introducing and lifting non-pharmaceutical interventions with the time-varying reproduction number $(R)$ of SARS-CoV-2: a modelling study across 131 countries. Lancet Infect Dis. 2021;21(2):193-202. 